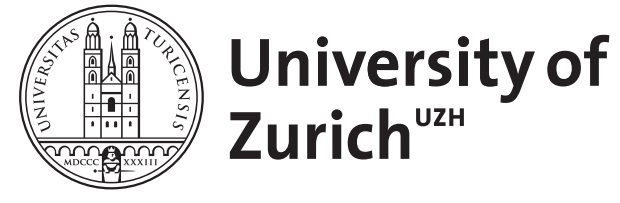

\title{
Control of energy homeostasis by amylin
}

\author{
Lutz, T A
}

\begin{abstract}
Amylin is an important control of nutrient fluxes because it reduces energy intake, modulates nutrient utilization by inhibiting postprandial glucagon secretion, and increases energy disposal by preventing compensatory decreases of energy expenditure in weight-reduced individuals. The best investigated function of amylin which is cosecreted with insulin is to reduce eating by promoting meal-ending satiation. This effect is thought to be mediated by a stimulation of specific amylin receptors in the area postrema. Secondary brain sites to mediate amylin action include the nucleus of the solitary tract and the lateral parabrachial nucleus, which convey the neural signal to the lateral hypothalamic area and other hypothalamic nuclei. Amylin may also signal adiposity because plasma levels of amylin are increased in adiposity and because higher amylin concentrations in the brain result in reduced body weight gain and adiposity, while amylin receptor antagonists increase body adiposity. The central mechanisms involved in amylin's effect on energy expenditure are much less known. A series of recent experiments in animals and humans indicate that amylin is a promising option for anti-obesity therapy especially in combination with other hormones. The most extensive dataset is available for the combination therapy of amylin and leptin. Ongoing research focuses on the mechanisms of these interactions.
\end{abstract}

DOI: https://doi.org/10.1007/s00018-011-0905-1

Posted at the Zurich Open Repository and Archive, University of Zurich

ZORA URL: https://doi.org/10.5167/uzh-56281

Journal Article

Published Version

Originally published at:

Lutz, T A (2012). Control of energy homeostasis by amylin. Cellular and Molecular Life Sciences, 69(12):1947-1965.

DOI: https://doi.org/10.1007/s00018-011-0905-1 


\title{
Control of energy homeostasis by amylin
}

\author{
Thomas A. Lutz
}

Received: 19 August 2011/Revised: 13 November 2011/Accepted: 6 December 2011/Published online: 23 December 2011 (C) Springer Basel AG 2011

\begin{abstract}
Amylin is an important control of nutrient fluxes because it reduces energy intake, modulates nutrient utilization by inhibiting postprandial glucagon secretion, and increases energy disposal by preventing compensatory decreases of energy expenditure in weight-reduced individuals. The best investigated function of amylin which is cosecreted with insulin is to reduce eating by promoting meal-ending satiation. This effect is thought to be mediated by a stimulation of specific amylin receptors in the area postrema. Secondary brain sites to mediate amylin action include the nucleus of the solitary tract and the lateral parabrachial nucleus, which convey the neural signal to the lateral hypothalamic area and other hypothalamic nuclei. Amylin may also signal adiposity because plasma levels of amylin are increased in adiposity and because higher amylin concentrations in the brain result in reduced body weight gain and adiposity, while amylin receptor antagonists increase body adiposity. The central mechanisms involved in amylin's effect on energy expenditure are much less known. A series of recent experiments in animals and humans indicate that amylin is a promising option for anti-obesity therapy especially in combination with other hormones. The most extensive dataset is available for the combination therapy of amylin and leptin. Ongoing research focuses on the mechanisms of these interactions.
\end{abstract}

T. A. Lutz ( $\square)$

Institute of Veterinary Physiology, Vetsuisse Faculty University of Zurich, Winterthurerstrasse 260, 8057 Zurich, Switzerland e-mail: tomlutz@vetphys.uzh.ch

T. A. Lutz

Zurich Center for Integrative Human Physiology,

University of Zurich, Zurich, Switzerland
Keywords Amylin · Amylin receptor - Satiation · Adiposity $\cdot$ Histamine $\cdot$ Leptin $\cdot$ Estradiol

\section{Introduction}

This review focuses on three aspects of amylin's roles in the control of eating and energy homeostasis. In the first part, the current knowledge on how the hindbrain mediates amylin action is summarized. An interesting phenomenon is that there is a large overlap in various areas between different satiating signals despite some differences at the behavioral level; in most instances, it is unknown how the brain differentiates between similar signals. Second, the potential role of amylin as adiposity signal in addition to its satiating action is discussed. Finally, based on the exciting data gained from animal experiments, the therapeutic potential of amylin in obesity, in particular using combination therapies, is discussed.

Pancreatic beta-cells are the major source of circulating amylin. Meal-associated fluctuations of circulating amylin levels are thought to directly reflect changes in beta-cell secretion; the contribution of other amylin-secreting cells to circulating amylin levels is considered minor. Further, it is also believed that fluctuations in beta-cell secretion like the postprandial increase are the physiological basis for amylin's effect on eating and energy homeostasis [1].

Mediation of amylin action by specific amylin receptors

Amylin actions are mediated by a membrane bound receptor which is also present in the area postrema (AP), the presumed primary site for most amylin actions (for review, see [2]). The amylin receptor is a heterodimer of the type-a or type-b calcitonin receptor (CTR) and receptor 
activity modifying proteins (RAMP). The CTR represents the core receptor protein which obtains specific amylin binding properties by co-expression of one of the known RAMPs in the same cell [3-5]. Amylin receptors typically derive from the co-expression of CTR with RAMP1 or 3 $[6,7]$; RAMPs confer specificity of the CTR to amylin by altering CTR pharmacology from calcitonin-preferring to amylin-preferring receptors. RAMPs regulate the transport of the core receptors to the cell surface and their glycosylation state and therefore influence ligand specificity $[4,8]$.

Amylin binds strongly to the AP; the CTR, RAMP1, and RAMP3 are all densely expressed in the AP; further, amylin-induced neuronal activation, as assessed by c-Fos mRNA colocalizes with CTR(a) and RAMP3 mRNA in the rat AP [9-12]. However, despite the evidence that all structural components of functional amylin receptors are present in the AP, and that the AP is necessary for amylin action (see below), it still remains to be shown that the CTR, RAMP1, or RAMP3 all co-localize in amylin-sensitive AP neurons. Further, it has not yet been tested whether the site-specific ablation of one of the critical components of the functional amylin receptor in AP neurons is sufficient to abolish amylin action.

\section{Amylin acts as a satiation signal (see also Fig. 1 for working model of amylin action)}

The best investigated function of amylin is the role as a signal of satiation [13]. In the complex system that controls eating, amylin is believed to be a physiological control of meal size $[14,15]$, because it meets the critical criteria for a physiological endocrine satiation signal. First, in humans, rats and other species food intake leads to a marked and rapid increase in plasma amylin concentration within minutes after meal onset; this increase correlates with the amount eaten $[16,17]$. In rats, eating a $5 \mathrm{~g}$ test meal after an overnight fast leads to an immediate rise in endogenous plasma amylin levels from about 3-5 to $15-20 \mathrm{pmol} / \mathrm{l}$ within 5-10 min. Second, functional amylin receptors, i.e. the heterodimers of CTR plus RAMPs appear to be expressed in the AP and the AP is necessary for amylin's effect on eating. Third, low, near physiological doses of exogenous amylin that increase plasma amylin levels only about two times compared to postprandial levels inhibit eating [18]; considering the many interactions of amylin with other controls of eating and the enhanced eating inhibitory effect by their combined administration [19-21], we presume that this important criterion is therefore sufficiently met. Fourth, amylin-deficient mice have been used to study the specific removal of amylin [22]. These mice show some expected phenotypes, such as (at least

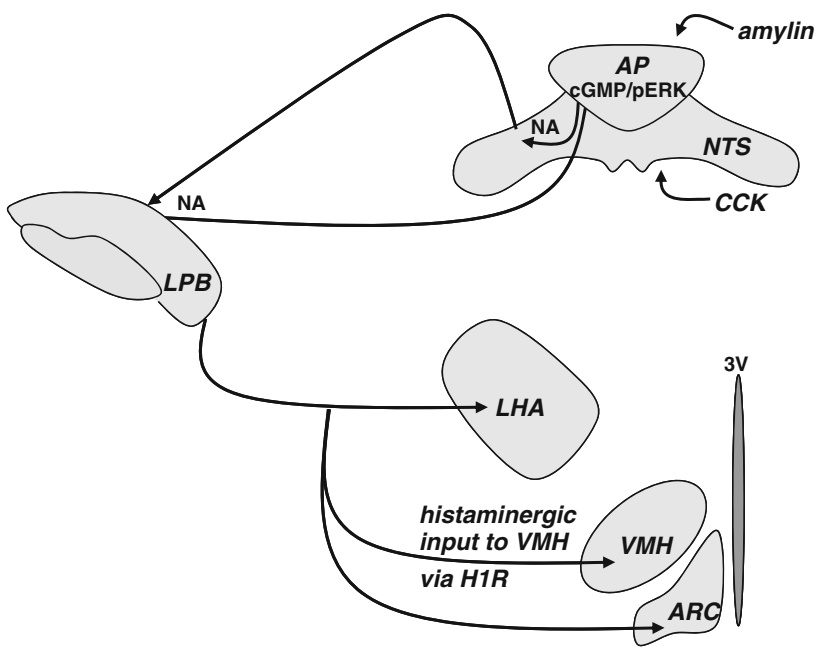

Fig. 1 Satiation diagram. The working model assumes that noradrenergic $(N A)$ neurons in the area postrema $(A P)$ mediate amylin's satiating effect. Intracellular signaling systems involved in amylin action include $c G M P$ and $p E R K$ but their necessity for amylininduced NA neurotransmission needs to be investigated. AP projections reach the lateral parabrachial nucleus $(L P B)$ directly or indirectly via the nucleus of the solitary tract $(N T S)$. The NTS is the most likely site for the interaction between cholecystokinin $(C C K)$ and amylin. Projections from the LPB reach several hypothalamic nuclei such as the lateral hypothalamic area $(L H A)$, the ventromedial hypothalamus $(V M H)$ where histamine receptors of the H1 subtype $(H 1 R)$ may be involved and where amylin interacts with leptin (see also Fig. 2), and perhaps the hypothalamic arcuate nucleus (ARC). $3 \mathrm{~V}$ third cerebral ventricle

temporary) overeating and increased adiposity [23, 24]. However, whether these changes persist throughout life and whether they can be rescued by amylin replacement still needs to be studied; at least under acute conditions, amylin reduces eating in amylin knockout mice in a way similar to wildtype controls. Fifth, amylin antagonists like AC187 increase eating and meal size when administered peripherally [25] or centrally [26]; AC187 administered into the AP blocks the anorectic effect of peripheral amylin and stimulates eating and intake by an increase in meal size [27]. Finally, amylin and amylin analogues reduce meal size without producing signs of conditioned taste aversion or visceral illness [28-31]. Overall, the data indicate that amylin acts as a physiological satiating hormone in rats. Amylin does produce comparable behavioral effects in humans but the crucial tests for its physiological relevance in humans have not yet been done.

Amylin action in the brainstem

The AP is one of several brain regions that show strong amylin binding in amylin receptor autoradiography studies [12]. The anorectic effect of amylin seems to be mediated by a direct humoral action on neurons in the AP; this direct activation by circulating amylin is possible because the AP 
lacks a functional blood-brain barrier [32, 33]. Some of the data that indicate that activation of the AP is necessary for amylin's satiating effect are summarized here.

First evidence that the satiating effect of peripheral amylin is mediated by direct action on AP neurons was provided by studies showing that neither subdiaphragmatic vagotomy nor specific hepatic branch vagotomy or capsaicin-induced lesions of peripheral neural afferents that project to the brain reduced amylin's effect. Amylin's effect was, however, abolished in rats with specific AP lesions [31, 32, 34-38]. Further, local amylin administration into the AP reduced meal size and AC187 had the opposite effect; AC187 also abolished the eating inhibitory effect of peripheral amylin [27]. Consistent data were produced in electrophysiological and immunohistochemical studies which also suggested a direct influence of amylin on the AP [39-43]. Interestingly, the AP also seems to be necessary for amylin's action to inhibit gastric emptying, because ablation of the AP but not of vagal afferents blocks this effect [31, 44-47] (see also “Amylin's effect on gastric emptying is also mediated by AP neurons").

Brainstem intracellular mechanisms mediating amylin signaling

Numerous studies have investigated the specific intracellular signaling mechanisms that are activated by amylin and potentially mediate its action. Some of these studies relied on the use of neuronal activation markers such as c-Fos; more recent studies provided evidence for the necessity of certain other intracellular mechanisms for amylin action.

A commonly used marker for amylin-activated brain areas is based on the expression pattern of the immediate early gene product c-Fos detected by immunohistochemistry [9, 31, 42, 48, 49]. These experiments helped to define specific amylin-activated areas in the brain; in addition to the AP, the neuroaxis mediating amylin action also comprises the nucleus of the solitary tract (NTS) and the lateral parabrachial nucleus (LPB). However, the functional correlate of these findings remains unknown; in other words, whether amylin-induced c-Fos expression in the AP or other brain areas is necessary for amylin action is unknown. Specific tests in this respect have not yet been performed, but see also "AP neurons are also sensitive to nutrients".

Immunohistological c-Fos studies have also shown that exogenous and endogenous amylin activate the same brain structures. Meal access after a 24-h food deprivation period caused neuronal activation in the AP and NTS comparable to that of exogenous amylin, and this response in the AP was blocked by AC187. The latter indicates that endogenous amylin contributes to the activation of the AP in refed animals [42].

Despite its widespread use, the mapping of activated brain areas using c-Fos protein expression has several inherent disadvantages. As already mentioned, the functional role of c-Fos formation after amylin stimulation or other stimuli is not clear. First, the eating-inhibitory effect of acute amylin occurs within a few minutes after administration, but c-Fos-protein expression is typically not detectable before $30 \mathrm{~min}$ after the stimulus; the latter could, of course, also be due to the limited sensitivity of available antibodies for small amounts of c-Fos (which, however, may be biologically active) [50]. Second, c-Fos immunoreactivity reflects only one specific point in time, and third, it only depicts areas activated but not inhibited by a given stimulus.

Considering these disadvantages, cGMP formation may be more useful to depict amylin action in the AP. Immunohistological and electrophysiological studies suggested that amylin exerts excitatory effects in AP neurons that are mediated by an increased formation of the intracellular second messenger cyclic guanosine monophosphate (cGMP) [40]. Further, local AP injection of a membranepermeable analogue of cGMP decreased eating similar to amylin by a meal size effect [27]. Because most neurons showing increased formation of cGMP after amylin express the CTR (unpublished), formation of cGMP may be functionally involved in amylin's eating-inhibitory effect. However, it still needs to be tested whether cGMP formation in the AP is necessary for amylin to reduce eating, i.e. whether the inhibition of its formation prevents amylin's effect.

A series of recent experiments identified the extracellular signal-regulated kinase 1 and 2 (ERK 1/2) cascade as a useful intracellular marker for amylin action; in fact, rapid phosphorylation of ERK may be functionally involved in amylin's effect on eating. ERK $1 / 2$ is one of the four members of the mitogen-activated protein kinase family; it is a highly conserved signaling cascade and is involved in various cellular processes. Activation of this pathway leads to a rapid ERK1/2 phosphorylation which results in the activation of gene transcription but also in acute neuronal responses; the latter responses are typically linked to the activation or inhibition of ion channels and hence to neuronal excitability [51-54]. This feature makes the ERK cascade an interesting candidate signaling system for the study of many rapid behaviors, including meal termination by satiating peptides like amylin.

Because amylin had been demonstrated to stimulate ERK signaling in osteoclasts which carry specific amylin receptors $[7,55]$, we recently tested whether amylin activates this signaling pathway in the AP and whether this may be functionally relevant for amylin action. In fact, 
amylin time- and dose-dependently induced ERK phosphorylation in the AP with a peak effect between 10 and 15 min after peripheral amylin, which is at a time when amylin's satiating effect is fully developed [28, 39]. Further, amylin-induced ERK phosphorylation in AP neurons partly overlapped with positive staining for the CTR, indicating that the ERK cascade seems to be activated in amylin-sensitive AP neurons; pERK staining also overlapped with the expression of dopamine-beta-hydroxlase $(\mathrm{DBH})$, a key enzyme in noradrenaline synthesis (see below and [56]). Finally, prior administration of U0126, an inhibitor of ERK phosphorylation into the 4th brain ventricle, reduced the acute eating inhibitor effect of amylin at least under certain experimental conditions [43, 56]. Overall, these studies indicate a potential functional role of ERK cascade activation in amylin's anorectic effect.

It had previously been demonstrated that the ERK pathway is activated in the NTS by the administration of peripheral CCK; similar to amylin, the anorectic action of CCK seems to critically depend on this pathway because pharmacological blockade of ERK phosphorylation by U0126 attenuated CCK's immediate anorectic response $[57,58]$. Interestingly, the NTS is a site of convergence for a variety of anorectic signals including amylin, which may modulate CCK's anorectic effect via the AP/NTS region $[19,59]$.

One result of the amylin-induced activation of AP neurons seems to be an increased expression of $\mathrm{DBH}$, the key enzyme in noradrenaline synthesis, and the subsequent release of noradrenaline possibly in the NTS or LPB [56]. Recent studies indicate that noradrenergic neurons within the AP mediate amylin's anorexigenic effects. First, a large proportion of amylin-activated AP neurons are noradrenergic because the number of DBH and c-Fos double-labeled neurons was higher in amylin- than in saline-injected rats [56]. Second, a specific lesion of about $50 \%$ of all noradrenergic neurons in the AP with the chemotoxin saporin was sufficient to abolish the anorexigenic effect of peripheral amylin. Third, the saporin-induced lesion of these NAneurons also reduced amylin's ability to induce c-Fos expression in AP neurons; the number of amylin-activated neurons correlated with the number of remaining NA-neurons in the AP, indicating that rats with larger NA-lesions, and hence fewer remaining DBH-positive neurons, also displayed lower numbers of amylin-activated AP neurons.

AP neurons are also sensitive to nutrients

Amylin-sensitive AP neurons also seem to act as direct sensors for a variety of nutrients. Electrophysiological studies have, e.g., shown that amylin and glucose co-activate AP neurons [41]. A direct functional correlate of the amylin and glucose co-sensitivity of AP neurons has been described in respect to amylin's effect to reduce the rate of gastric emptying (see also "Amylin's effect on gastric emptying is also mediated by AP neurons"); this effect was absent under hypoglycemic conditions [60]. Similarly, recent studies indicated that amylin reduced eating in rats under euglycemic and hyperglycemic, but not under hypoglycemic, conditions (unpublished). Teleologically, it seems plausible that amylin's action to inhibit nutrient availability should be restricted to situations when energy stores are plentiful, and that amylin should not limit the supply of nutrients at a time when they are urgently needed.

Recent findings indicate that dietary protein may also influence the action of amylin on AP neurons. Considering the general assumption that increased c-Fos expression exemplifies neuronal activation [50], and that amylin reduces eating via the AP [32], it was surprising that a low dose of peripheral amylin that decreased eating induced strong c-Fos expression in the AP of 24-h fasted rats, but not in rats fed ad libitum [61]. Interestingly, amylin also induced a strong c-Fos response in rats fed a nutrientdeficient non-caloric mash (NCM). Subsequent trials with nutrient specific supplementation of the NCM diet suggested that protein or perhaps single amino acids, but not fat or carbohydrates, attenuate the amylin-induced c-Fos response in the AP. Finally, parenteral injection of an amino acid mixture also attenuated the amylin-induced c-Fos expression in the AP in fasted rats, and amylin's anorectic action was stronger in rats fed a $1 \%$ protein diet ( $1 \%$ weight/weight) compared to rats fed an isocaloric diet with higher protein content $(8-18 \%)$ [61, 62]. The mechanisms underlying these phenomena and the functional implications are not clear, and it needs to be tested whether specific amino acids may directly reduce the effect of amylin to activate AP neurons. Interestingly, these studies do show that the effect of amylin to reduce eating and to induce c-Fos expression may be dissociated under certain conditions.

Amylin's effect on gastric emptying is also mediated by AP neurons

The stomach and gastric emptying play an important role in the overall control of eating [63]. Gastric wall distension produces an anorectic signal that is conveyed to the central nervous system, and in particular to the NTS via gastric vagal and splanchnic afferents [64-66]. Most but not all [28] studies suggested that anorectic doses of amylin also reduce gastric emptying in rats and humans [46, 67, 68]; the effect seems to be physiologically relevant because AC187 accelerated gastric emptying in rats [69].

These observations are interesting regarding the phenomenon of accelerated gastric emptying in human type 1 diabetics and insulin-requiring type 2 diabetics; this defect 
contributes to postprandial hyperglycaemia and may therefore be responsible for part of the negative long-term consequences of diabetes mellitus (e.g. [70]). The amylin analogue pramlintide has similar effects in human patients like amylin in rats, and amylin, but not insulin, normalizes gastric emptying in animal models of type 1 diabetes [46, 67, 71-74]. Similar to amylin's anorectic action, the effect on gastric emptying seems to depend on a direct action in the AP [44] but not on vagal afferents [47, 75, 76]. Interestingly, amylin's inhibitory effect on gastric emptying is overridden under hypoglycaemic conditions (see also "AP neurons are also sensitive to nutrients"; [60]); this is possibly explained by the co-sensitivity of AP neurons to amylin and glucose [41].

Because the lowest effective amylin doses to reduce meal size or to slow gastric emptying are comparable [77], it was postulated that amylin's effect on gastric emptying contributes to amylin's anorectic effect under normal feeding conditions; however, the former effect does not seem to be necessary for the latter to occur. First, both effects are pharmacologically distinguishable [1,78], and second, amylin also reduces eating under sham-feeding conditions and, hence, when gastric and postgastric feedback signals are eliminated [79]. Because higher doses were necessary to reduce sham-feeding than real-feeding [79], amylin may synergistically interact with other negative feedback signals to reduce food intake; these may include gastric feedback [77], CCK [19, 21, 59, 79], and possibly other signals [20].

Amylin's anorectic effect is not secondary to a reduction in drinking

Because food intake is usually coupled to water intake [80], reduced drinking could theoretically lead to a secondary reduction in eating. There is, however, so far no experimental evidence that amylin reduces eating secondary to an effect on water intake; while amylin induces a parallel reduction of eating and drinking when both food and water are present, an independent primary amylininduced reduction of drinking in the absence of food has not been documented [29, 35, 81]. Further, amylin did not reduce water intake in a sham feeding paradigm [79]. This suggests that the inhibitory effect of amylin on water intake in the presence of food, i.e. when an anorectic effect is present, is secondary to a reduction in feeding.

\section{Neural pathways beyond the AP processing amylin signaling}

The combination of receptor binding studies ([12]; see also [9]), behavioral experiments with local injections [27], and behavioral experiments with rats that carry lesions of the entire AP [31,32] or of specific neurons within the AP [56] all clearly indicate that the AP is the primary target for amylin and necessary for its action. The activation of AP neurons seems to be synaptically transmitted to the forebrain via the NTS and the LPB. Rats with lesions of the AP or the LPB do not eat less in response to amylin [32, 82]. Further, the amylin-induced c-Fos expression was absent in areas rostral to the site of lesion; hence, no c-Fos was observed in the NTS, LPB, and central nucleus of the amygdala (CeA) in AP-lesioned, or in the CeA in LPBlesioned, rats. Neuronal tracing studies with anterograde and retrograde tracers confirmed the direct links between these amylin-activated areas. These studies also identified the LPB as the primary relay between the hindbrain and the hypothalamus, including the lateral hypothalamic area (LHA), where amylin reduces fasting-induced c-Fos expression $[42,48]$, and the ventromedial hypothalamus (VMH) where histamine $\mathrm{H} 1$ receptors may be implicated in amylin's effect on eating [83].

Other gastrointestinal hormones that inhibit eating like cholecystokinin (CCK), glucagon-like peptide 1 (GLP-1), and peptide YY 3-36 (PYY) all produce relatively similar activation patterns in the brain [21, 49, 84-87], but it remains unclear how the brain distinguishes between these different inputs. At present, the most commonly used technique to study brain activation, i.e. c-Fos immunocytochemistry, is very useful to define a general activation pattern. However, and as briefly discussed above, the use of c-Fos is limited because only one specific time point can be assessed from a single animal, because only neuronal activation but not neuronal inhibition is detected, and because c-Fos is expressed only after the behavioral satiating response has occurred. If the various satiation signals acted at slightly different time points across a meal, it seems rather unlikely that the poor temporal resolution of c-Fos immunostaining would allow the capturing of these differences. Hence, the functional implications of c-Fos expression in respect to the process of satiation remain unknown. Alternative strategies like in vivo imaging, perhaps using functional magnetic resonance, may help to characterize more specifically and in a time-dependent manner the brain pathways specifically for each signal.

Role of histamine in amylin signaling

Hypothalamic histamine is involved in the control of food intake and body weight [88-92]. Increased concentrations of central histamine reduce feeding via histamine $\mathrm{H}_{1}$ receptors [90, 93], whereas a blockade of central histamine $\mathrm{H}_{1}$ receptors increases food intake. Additional studies showed that the $\mathrm{H}_{1}$ receptors in the VMH and 
paraventricular (PVN) hypothalamic nuclei, which are the areas richest in hypothalamic histamine and $\mathrm{H}_{1}$ receptors $[89,94]$, play the major role in this regard [89].

Various studies underlined the importance of histamine and in particular of $\mathrm{H} 1$ receptors in amylin's effect on eating. Part of these experiments was performed using $\mathrm{H} 1$ receptor-deficient mice (H1rKO mice). As expected, the $\mathrm{H}_{3}$ receptor antagonist thioperamide, which reduces food intake in rats [88] by enhancing the synthesis and release of endogenous histamine [95], produced no anorectic effect in $\mathrm{H}_{1} \mathrm{Rko}$ mice but only in wild-type (wt) controls [96]. Further, we also observed an increased body weight gain in $\mathrm{H}_{1}$ Rko mice compared to wt controls; this was associated with an increased fat pad mass [97] and a slight increase in basal food intake in the $\mathrm{H}_{1}$ Rko mice. Hence, the phenotype of the H1rko mice is consistent with the overall importance of the histaminergic system and $\mathrm{H}_{1}$ receptors in the control of food intake and body weight.

Functional $\mathrm{H}_{1}$ receptors seem to be essential for amylin or its agonist salmon calcitonin (sCT) to reduce eating. sCT is structurally and functionally related to amylin [98] and reduces feeding by interaction with amylin receptors [99]. The stronger and prolonged effect of sCT compared to amylin [99] can be explained by sCT's irreversible binding to amylin receptors [100] and their persistent activation [101]. The latter seems to occur without significant receptor desensitization. In contrast to wt control animals, the anorectic actions of amylin and of sCT were absent in $\mathrm{H}_{1} \mathrm{Rko}$ mice unless extremely high doses were used [96, 97]. It is important to note that the lack of H1 receptors did not produce an unspecific insensitivity to anorectic stimuli because the H1rko mice exhibited a normal response to anorectic doses of CCK [96]; consequently, histamine $\mathrm{H}_{1}$ receptors are not necessary for the transmission of CCK's anorectic action. These data confirm previous studies that CCK's anorectic effect does not depend on the histaminergic but rather the serotoninergic system [102], and they also underline the specificity of the observed effects in respect to amylin or amylin agonists.

The findings in the H1rko mice complemented previous studies. First, we had demonstrated that pretreatment of rats with the $\mathrm{H}_{3}$ receptor agonists imetit or R- $\alpha$-methylhistamine, which block the release of endogenous histamine via presynaptic histamine $\mathrm{H}_{3}$ receptors, reduced amylin's inhibitory effect on feeding in rats [102]. Further, amylin did not reduce eating in rats that were pretreated with the $\mathrm{H} 1$ receptor antagonist chlorpheniramine administered directly into the VMH [83]. Overall, we therefore concluded that the amylin-induced activation of AP neurons directly or indirectly leads to an increase in hypothalamic histamine release to bring about amylin's

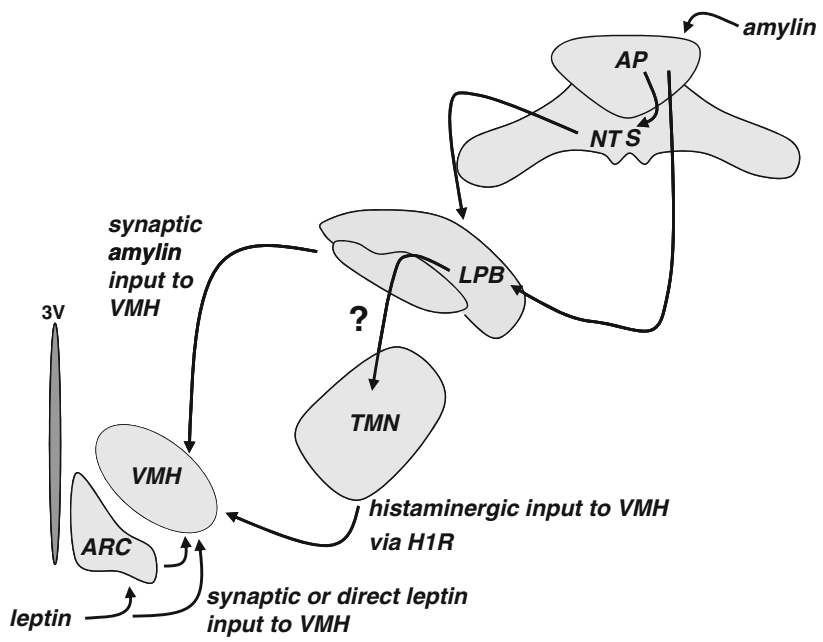

Fig. 2 Adiposity signal diagram. The working model assumes that the potential role of amylin as adiposity signal requires a primary amylin action via the area postrema $(A P)$. AP projections via the lateral parabrachial nucleus $(L P B)$ reach the ventromedial hypothalamus $(V M H)$ where amylin interacts with leptin. Because amylin deficient mice have a lower expression of leptin receptors in the mediobasal hypothalamus, the leptin/amylin interaction in the VMH may depend on a direct action of leptin on VMH neurons; however, the potential role of an indirect input via the hypothalamic arcuate nucleus $(A R C)$ requires further studies. Histamine receptors of the $\mathrm{H} 1$ subtype $(H 1 R)$ may be involved in the leptin/amylin interaction but the signal that triggers histamine release from neurons in the tuberomamillary nucleus $(T M N)$ is unknown. $3 \mathrm{~V}$ third cerebral ventricle

effect by acting on hypothalamic histamine $\mathrm{H}_{1}$ receptors, most likely within the VMH (see also Figs. 1,2).

The H1rko mice also provided interesting findings in respect to leptin. Morimoto et al. and Yoshimatsu et al. $[103,104]$ had already shown that the central histaminergic system is involved in leptin's anorectic effect because a specific inhibitor of histidine decarboxylase $(\alpha-$ fluoromethylhistidine; FMH), which is a key enzyme in histamine synthesis, abolished the anorectic effect of leptin in mice; further, leptin's inhibitory effect on feeding was absent in $\mathrm{H}_{1}$ Rko mice [104, 105]. The latter was also confirmed by us [96]; only very high leptin doses produced some reduction in eating [97], indicating that other neurotransmitters also seem to be involved in leptin action [106].

Together, these findings raise the question whether the central nervous signaling pathways for amylin which acts through activation of AP neurons, and leptin which acts primarily via the hypothalamus, converge via the histaminergic system in the VMH. This conclusion is plausible for several reasons. First, the primary sites for amylin (AP) and leptin action [the arcuate nucleus (ARC), but also the VMH, see below; [107]] appeared to be activated normally 
in H1rko mice when gauged by c-Fos (amylin) and pSTAT3 (leptin), respectively [97]. Second (see also discussion in "Pharmacological interactions of amylin with leptin in animals"), amylin increased leptin's effect to induce pSTAT3 formation in the hypothalamic ARC but also in the VMH in obese, amylin-pretreated rats [108]. In other words, amylin restored the leptin-induced immunoreactivity of pSTAT3, and therefore presumably the leptin sensitivity of the $\mathrm{VMH}$, in obese rats to a level similar to lean rats. Further, acute amylin treatment upregulated leptin receptor expression and increased leptin binding in the rat VMH [109]. Finally, our preliminary studies indicated that amylin/leptin combination treatment lowers food intake in wt but not in H1rko mice [97]. What remains to be studied is whether histamine and $\mathrm{H} 1$ receptors are specifically necessary for this interaction to occur or whether they "simply" mediate the anorectic effects of amylin and leptin by, in principle, independent mechanisms.

The studies discussed above clearly implicated noradrenergic neurons in the AP (see also "Brainstem intracellular mechanisms mediating amylin signaling"; [56]) and $\mathrm{H} 1$ receptors presumably in the $\mathrm{VMH}[83,96]$ in amylin's anorectic effect. We had also shown in previous studies that the dopaminergic system may be involved in amylin's satiating effect because blockade of $\mathrm{D}_{2}$ receptors attenuated amylin's action in rats [110]. Further, immunohistochemical studies showed a marked overlap of cells with amylin-induced c-Fos expression and cells expressing tyrosine hydroxylase $(\mathrm{TH})$, the rate-limiting enzyme in dopamine synthesis. Finally, a high density of dopamine $\mathrm{D}_{2}$ receptors has been detected in the AP/NTS region [111], and an infusion of the dopamine $\mathrm{D}_{2}$ antagonist raclopride directly into the AP/NTS region attenuated the amylin-induced reduction of feeding. Hence, we concluded that a dopaminergic system in the brainstem is involved in the ascending signaling pathway mediating the anorectic effect of amylin. The direct relationship between noradrenergic and dopaminergic signaling remains to be elucidated.

All studies combined, our working model therefore includes an interaction of the noradrenergic and possibly dopaminergic system in the hindbrain and a sequential involvement of hypothalamic nuclei including the histaminergic system in the VMH as mediators of amylin's anorectic effect $[2,48]$. The latter may also be responsible for the interaction of amylin and leptin. In other words, the amylin-induced activation of AP neurons seems to lead to a release of noradrenaline and potentially of dopamine acting in the hindbrain [2,13], which then directly or indirectly influence hypothalamic histamine release to bring about amylin's effect by acting on hypothalamic histamine $\mathrm{H}_{1}$ receptors.
Amylin as adiposity signal (see also Fig. 2 for working model of amylin/leptin interaction)

Introduction-distinction between satiation and adiposity signals

The current concept of homeostatic eating controls involves adiposity or "tonic" signals that enhance the effect of satiation and other meal-associated or "episodic" signals. This concept helps to structure the large number of signals implicated in the complex system controlling eating. Adiposity signals appear to affect eating by enhancing the effects of satiation signals. For example, amylin, similar to leptin and insulin, enhances CCK's satiating effect [19, 59, 112, 113].

This concept of distinct satiation versus adiposity signals also bears some discrepancies because particular signals are not always clearly classified as either adiposity or meal-associated signals. Insulin, e.g., has been hypothesized to be an adiposity signal [114], but insulin is also released during meals, and blockade of endogenous insulin by insulin antibodies increased meal size [115]. Insulin may therefore contribute to the control of meal termination. A similar situation may apply to amylin. Although amylin, like CCK, produces meal-terminating satiation, amylin and CCK differ in some important aspects. In particular, rats infused continuously with CCK do not show sustained reductions in food intake and body weight [116]; further, rats intraperitoneally infused with CCK prior to each spontaneous meal had reduced meal sizes throughout the test, but reduced total food intake and body weight were only seen initially because of a compensatory increase in meal frequency [117]. No such compensation occurs with chronic amylin infusions even though the main direct behavioral effect for CCK and amylin is a sustained reduction in meal size $[28,81]$. One could perhaps speculate that the decrease in meal size is due to a satiating action of amylin, whereas the lack of compensatory changes in meal frequency is due to a separate "adiposity" action, potentially activating other neural circuits; the latter may not be instrumental in the case of CCK.

Because amylin appears to function as both adiposity (see later in this section) and satiating signals, one may ask whether tonic levels of amylin influence the satiating effect of phasic changes in amylin levels. Data are scarce. However, adult amylin-deficient mice eat less after acute peripheral amylin; further, acute amylin reduced eating to a similar extent independent of the underlying baseline amylin concentration ([118]; see later in this section). Hence, at least the acute effect of amylin to reduce eating does not require pre-existing endogenous amylin nor does the effect seem to be stronger when baseline amylin levels are high. 
More generally, one may ask if the distinction between adiposity versus meal-control signals is useful in light of the current understanding of the dual actions of amylin, insulin $[114,115,119]$, and perhaps other eating controls. The distinction would seem to be useful if the brain processed the information differently; it could even be argued that the utility of the concept of adiposity versus mealcontrol signals only makes sense based on evidence of distinct neural processing. In such cases, e.g., if the two types of effects were mediated at different sites, one could imagine that lesioning one site would prevent one effect but not the other. Both the acute satiating effect and the chronic adiposity effect of amylin on eating, however, seem to require an intact AP $[32,37]$. Whether subsequent processing of the two signals in projection areas of AP neurons depends on different brain areas or other populations of neurons has not been tested.

\section{Evidence for amylin being an adiposity signal}

Evidence indicating that amylin may act as an adiposity signal is based on several findings. First, basal plasma levels of amylin are increased in obese versus lean rats [120]; of note, lean and obese rats in that study markedly differed in age, but age per se does not seem to influence basal amylin [121]. Second, high fat-fed obese rats had higher baseline amylin levels than age-matched lean controls [118, 122]; of note, the design of that study did not allow distinguishing clearly between a body weight and a diet effect. Third, basal and glucose-stimulated plasma amylin levels were also elevated in obese humans [123, 124]. Together, these studies suggest a possible association between body adiposity and plasma amylin.

We recently investigated in more detail whether changes in body adiposity are reflected in altered (baseline) amylin levels and whether such changes in adiposity and amylin follow the same temporal pattern [125]. In that study, rats were rendered obese by chronic intragastric overfeeding. Plasma leptin, insulin, and amylin levels were determined during overfeeding which was stopped when rats had reached about $30 \%$ excess body weight above salineinfused normal weight rats; hormone levels were determined in the same animals after the termination of overfeeding. With the development of obesity, leptin and insulin levels increased markedly. To our surprise, basal amylin levels did not change significantly during this period or after termination of forced overfeeding. Based on the studies mentioned above $[118,126]$, where the relative increase in body weight was less pronounced, it seems unlikely that the extent of overweight was insufficient to cause major differences in plasma amylin [125]. It is, however, possible that amylin levels may only increase after extended periods of overweight because, in the study by Boyle et al. [118], rats had been fed with a high fat diet for 9 weeks, while Gloy et al. [125] measured plasma amylin after 4 weeks of overfeeding. Further, it is possible that the type of diet used during overfeeding may play a role. It seems clear that further studies are required to define the exact contribution of time, diet, extent of overweight, and other potential factors on the obesity-related increase in plasma amylin levels.

A second line of evidence that amylin may act as an adiposity signal is that chronic peripheral [30, 127] or central [128] amylin infusion decreased body weight gain specifically by reducing fat mass, while infusion of an amylin antagonist increased body adiposity [26]. Body fat loss in amylin-treated rats was even more pronounced than in pair-fed controls, indicating that the infusions most likely reduced eating and increased energy expenditure $[129,130]$. Further, chronic third ventricular administration of the amylin antagonist AC187 increased food intake and body adiposity, although body weight was unaltered [26]. Finally, the amylin knockout mouse is heavier than wildtype controls [17], but it is not yet clear whether amylin replacement therapy may reverse this phenotype.

Recent experiments provided insight into the specific role of central amylin as an adiposity signal [130]; in other words, we tested whether an elevation of central amylin leads to a sustained change of the target body weight. Similar to previous studies with leptin or insulin [114, 131], we tested rats whose energy status or body weight was manipulated, e.g., by 2-day food deprivation or by voluntary overfeeding for 3 weeks. Interestingly, chronic third ventricular amylin infusions led to lower body weight gain irrespective of these prior manipulations. The 2-day food deprivation led to a strong decrease in body weight in amylin- and saline-infused control animals. At refeeding, the saline-infused controls restored body weight rapidly to a level that was indistinguishable from saline-infused ad libitum fed rats; amylin-infused rats reached a body weight that was similar to amylin-infused ad libitum fed rats. At termination of the study, about 2 weeks after the start of the infusions, all amylin-infused rats had a lower body weight than saline-infused controls. In the second experiment, when body weight was first increased by offering an energydense palatable food for 3 weeks, central amylin infusion reduced body weight to the same level as in amylin-infused, chow-fed rats. Together, these data suggest that central amylin, like leptin or insulin, may encode the regulated level of body weight and hence may contribute to the relative constancy of body weight throughout adult life [130].

Resistance to the adiposity signals leptin and insulin

It is a well-described phenomenon that progressive obesity is typically associated with the development of resistance 
to the eating-inhibitory effects of exogenous leptin and insulin. In the case of leptin, a good indicator of an animal's sensitivity to leptin is the leptin-induced induction of pSTAT3, an intracellular signaling molecule that is instrumental in mediating leptin function [132]; a reduced leptin-induced pSTAT3 response in leptin target neurons correlates with a reduced eating inhibitory effect of leptin. Obesity-related resistance also appears to be partly due to changes in the blood-brain barrier permeability for leptin and insulin [133-137]; interestingly, similar but body weight-independent changes can already be induced by a relatively brief exposure to a high fat diet, i.e. before obesity develops [138-140]. Finally, hyperleptinemia which develops as a consequence of reduced sensitivity to leptin in obesity per se seems to reduce further the animals' sensitivity to the action of leptin [141].

Amylin sensitivity in the obese state

Much less is known about changes in the sensitivity to amylin with the development of obesity. Such knowledge about obesity-induced, and also high fat diet-induced, changes in amylin sensitivity is of utmost importance considering the potential of amylin-based pharmacotherapy for the treatment of obesity [142-148]. Hence, it is important to know whether similar to other adiposity signals like leptin but also to other satiating hormones like CCK [149-151], amylin action may also be affected by obesity or the chronic intake of diets high in fat [152].

Similar to leptin or insulin, amylin is also transported across the blood-brain barrier [153, 154], but it is unclear whether this transport is reduced in obesity; more importantly, even if it were reduced, a defect in amylin transport would actually be expected to have little influence on the biological action of amylin because of its action via the AP which is devoid of a blood-brain barrier.

We recently tested the hypothesis that obesity reduces the sensitivity to amylin in more detail. This included the question if factors that cause obesity (e.g., consumption of a high fat or palatable diet) or factors that are associated with obesity (e.g., hyperamylinemia) change amylin sensitivity independently of obesity (for details, see [118]). Rats were chronically maintained on a high fat diet; over the course of the study, rats seemed to retain full sensitivity to acute amylin compared to rats fed a standard chow diet for up to 11 weeks. Even at later time points, the acute amylin response was not lost completely though it was somewhat attenuated. Hence, the intake of a high fat diet alone did not seem to markedly alter amylin sensitivity because we would have expected to see an earlier decrease in amylin sensitivity. The exact factors that resulted in the attenuated sensitivity to peripheral amylin of rats maintained on the high fat diet are not clear. It seems plausible that metabolic changes that occur following the prolonged high fat diet intake and the subsequent development of obesity may modify amylin's efficacy; factors released from the enlarged visceral and subcutaneous fat depots, chronically elevated supraphysiological leptin levels or plasma metabolites (e.g., free fatty acids or triglycerides) alone or in combination may have contributed to the reduced amylin sensitivity.

One factor that is associated with the development of obesity, i.e. the increase in plasma amylin, was excluded as a likely cause of reduced amylin sensitivity in rats exposed to the high fat diet. As mentioned, increased circulating levels of amylin are present in obese rats and humans [120, 123, 124, 155]. Hence, based on recent studies that hyperleptinemia is required for the full development of leptin resistance in rats [141], and that increased circulating levels of $\mathrm{CCK}$ are implicated in a reduced sensitivity to CCK [149], we hypothesized that elevated circulating baseline amylin may decrease the sensitivity to acute exogenous amylin administration. However, when lean rats chronically infused with amylin were challenged with acute peripheral amylin, exogenous amylin administration decreased food intake dose-dependently under all conditions; in other words, amylin acutely decreased eating to a similar extent in all rats and regardless of circulating amylin levels [118, 122]. Importantly, the baseline amylin concentrations in these rats were elevated to levels that are typically observed in obesity (30-40 vs. $10-15 \mathrm{pmol} / 1$ in lean rats). Hence, at least under the experimental conditions of that study, a decrease in the sensitivity to the eating inhibitory effect of acute amylin was not apparent; downregulation of amylin receptors or a decrease in postreceptor signaling following hyperamylinemia therefore appears to be unlikely. Indirectly, the data also suggest that the rapid rise in circulating amylin following an acute injection, which mimics the rapid meal-induced amylin release [122], may be more critical for amylin's effect on food intake, regardless of prevailing basal amylin levels.

Short term changes in amylin sensitivity and food palatability

Highly palatable diets promote the development of obesity in humans but also in rats; diet-induced obesity in obesityprone rats can, e.g., be triggered by offering a highly palatable diet like liquid Ensure [156, 157]. Recent studies suggested that food palatability and specifically the exposure to Ensure can alter amylin sensitivity, at least temporarily. Naïve rats that were acutely exposed to palatable chocolate Ensure for 3 days appeared resistant to the eating inhibitory effect induced by acute central or peripheral amylin. High doses of central amylin were still active, suggesting that rats had not become completely 
amylin insensitive but that exposure to Ensure resulted in a shift of the dose response curve. Interestingly, rats maintained on the chocolate Ensure for 3 weeks, or rats that were switched back to a chow diet after the 3-day exposure, regained amylin sensitivity [158]. The original reports claimed that the chocolate flavor of Ensure contributes to overeating this diet [157]. Similarly, we also found that the chocolate flavor seems to play a key role; 3-day feeding with neutral-flavored Ensure, which is nutritionally identical to the chocolate-flavored variety, did not result in amylin resistance. Hence, the high palatability and the novelty of the palatable chocolate Ensure seem to have created a strong signal to eat that overcame the satiating effects of acute amylin unless very high doses were used. Whether amylin action is directly influenced by the rewarding properties of food remains to be studied. Further, the role of the nucleus accumbens in these effects of amylin remains to be studied in more detail; the accumbens is typically associated with motivational and rewarding aspects of food [159].

To summarize, we observed reduced amylin sensitivity under some but not all experimental conditions. Because most of these conditions would typically be associated with leptin resistance, it seems that the mechanisms underlying the known instances of amylin and leptin insensitivity are likely to be quite different. In contrast to leptin resistance, where central leptin receptor function seems to be compromised, particularly in its presumed primary sites of action in the ARC and $\mathrm{VMH}$, amylin receptor function in the AP was similar in lean chow-fed or obese rats with dietinduced obesity, at least when gauged by c-Fos expression. This indicates that amylin insensitivity may not be caused by direct changes in amylin receptor function, but it needs to be tested whether intracellular signaling systems like cGMP and pERK, which are directly implicated in amylin action [39, 40, 43], are affected by body adiposity or diet composition. As mentioned before, while decreased leptin transport across the blood-brain barrier appears to play a role in leptin resistance [137], such an effect is unlikely to be of relevance for amylin. Finally, while hyperleptinemia seems required for the full development of leptin resistance [141], rats with elevated plasma amylin seem to be fully responsive to acute amylin injections [118, 122]. Overall, our results suggest that amylin sensitivity seems dynamic and may be influenced by diet composition, diet palatability, time of diet exposure, and metabolic state [118, 122, 158]); however, in all cases, at least high doses of amylin still caused a significant effect on eating.

Amylin secretion in the obese state

To search for potential causes of obesity, it is imperative to understand the entire physiology of the controls of eating and their role in the development of obesity. In that sense, malfunctioning of a physiologically relevant anorectic signaling system may not only be due to the insensitivity of that system in obesity, or even before overt obesity becomes apparent, but it could also be due to reduced secretion of this factor.

Based on this background, we recently investigated how obesity or maintenance on a high fat diet may alter eatinginduced amylin release.

As mentioned, basal levels of amylin are often elevated in obese humans and in rodent models of obesity. However, whether the meal-contingent release of amylin is affected by diet composition and whether the release pattern differs between obese and non-obese rats had not been tested before. In a recent study [122], we reported levels of amylin and insulin in several groups of age-matched rats just before and after a meal in hepatic portal vein blood samples. The rats were high fat-fed diet-induced obese or diet-resistant rats $[157,160,161]$ or chow-fed controls. Interestingly, both the high fat diet which had been offered for 8 weeks and obesity appeared to influence the mealinduced amylin release. Exposure to the high fat diet affected the baseline amylin levels because diet-resistant rats which actually had the lowest body weight of all groups had elevated baseline amylin. Further, all rats on the high fat diet demonstrated an earlier meal-induced rise in plasma amylin compared to the chow control group.

We also analyzed the amylin-to-insulin concentration ratio. This ratio is approximately 0.01 in lean humans and rodents [16, 162], and it is typically elevated in the obese state. An elevated ratio has also been reported to be associated with chronic hyperglycemia in rats and with glucose intolerance in obese humans [163, 164]. In our study, we observed comparable insulin concentrations in response to the test meal in all groups, but the diet-resistant rats had significantly higher basal amylin-to-insulin ratios than all other rats; this ratio remained higher than the chow-fed rats during the meal. This finding is, in principle, in agreement with a recent report demonstrating that elevated fatty acids enhanced the mRNA expression and release of amylin, but not insulin [165]. However, because the exact physiological and clinical relevance of changes in the amylin-toinsulin ratio is unknown, the implications of these findings need to be studied in detail.

Overall, it seems that the differential meal-induced secretion pattern suggests that the ratio at which amylin and insulin are secreted during a meal is influenced by both body composition and diet composition. We did not observe any indication of deficient amylin secretion in obesity or in the rats exposed to the high fat diets. In other words, it seems very unlikely that deficient amylin secretion may contribute to the development of obesity under the conditions tested. 


\section{Amylin and energy expenditure}

Energy homeostasis not only depends on controls of energy intake but also on controls of energy expenditure. Amylin, similar to leptin, may influence both legs of this control system because there are several reports from different laboratories that acute and chronic amylin administration increase energy expenditure in rodents [30, 127, 166, 167]; respective studies in humans have not yet been performed.

Isaksson and colleagues [166] showed that chronic peripheral amylin reduced body adiposity more than pair feeding in a group of control rats; this was associated with increased fat oxidation supplying energy for increased energy expenditure. Similarly, chronic peripheral amylin reduced body weight and body adiposity more than in pairfed control rats, and amylin increased total whole body energy expenditure [30, 127]; the latter effect may in part have been attributable to a relative increase in metabolically more active lean body mass, because the effect disappeared when energy expenditure was expressed per lean body mass [127].

In our own studies, we showed that amylin increased energy expenditure acutely when given at low doses into the third cerebral ventricle or directly into the AP [130, 168]. A decrease in energy expenditure is the typical metabolic reaction in weight-reduced rats; this decrease was prevented by chronic central amylin infusion despite its body weight-lowering effect. Amylin also lowered the respiratory quotient in our experiments, but reports in this respect are inconsistent. Peripheral acute administration of amylin [67, 129], and in particular of its longer acting agonist sCT [67, 68, 99, 130], increased energy expenditure in rats or, as in the chronic studies mentioned above, prevented the expected decrease in energy expenditure of rats that eat less. The action of acute peripheral SCT to increase energy expenditure was observed within minutes after administration [129].

Overall, the studies indicate that peripheral and central amylin seem to increase energy expenditure or at least to prevent the compensatory decrease in energy expenditure that is typically seen in animals that eat less or that are weight-reduced. Even though amylin's effect on energy expenditure seems to be robust and has been reproduced by various groups, the physiological relevance is not yet clear because the role of endogenous amylin in the control of energy expenditure has not been tested so far. In other words, the effect of a blockade of endogenous amylin on energy expenditure or energy expenditure in amylin-deficient mice has not been studied in detail. Further, the site and mechanisms of amylin's actions on energy expenditure remain to be determined. While local infusion of amylin into the AP increased energy expenditure acutely, further studies are necessary to clarify if the AP is necessary and sufficient for this effect, in particular for the effect of peripheral amylin. It is, however, likely that the effect is mediated by the central nervous system because markedly lower doses of amylin were highly effective when given centrally rather than peripherally $[129,130,167]$. In terms of mechanisms of action, it seems unlikely that increased physical activity played an important role [129]; further, body temperature was increased by amylin in some [129] but not all studies, and amylin did not change the expression of uncoupling protein [127]. Whether amylin affects heat dissipation has not yet been tested.

\section{Pharmacological interactions of amylin with leptin in animals}

Recent research suggests that leptin and amylin interact functionally in the control of eating. The combination of amylin and leptin and their potent interaction are the promising basis for the development of effective antiobesity therapies.

In an initial report, we found that acute central leptin injection increased the eating-inhibitory effect of peripheral amylin [169]; insulin had a similar effect on amylin action $[169,170]$.

Two-week peripheral infusions of amylin and leptin were performed in leptin-resistant rats with diet-induced obesity; importantly, leptin doses that were effective in lean animals were used, but the same doses had no detectable effects on eating or body weight in obese rats [108]. Consistent with previous reports, amylin was effective in the obese rats because it significantly reduced eating and led to a small, but significant, decrease in body weight. Rats that were pair-fed to the amylin group and that received leptin did not lose more weight than amylintreated rats. However, the combined application of exogenous leptin and amylin decreased both eating and body weight more than amylin alone, and body fat after leptin/ amylin was lower than in rats receiving amylin or in rats receiving leptin and that were pair-fed to amylin-treated rats. In other words, amylin infusion enhanced the sensitivity of obese rats to the catabolic effect of leptin [108]. Importantly, the leptin/amylin combination also increased dark-phase energy expenditure [108].

Follow-up experiments using several dose combinations confirmed the synergistic effect of amylin and leptin on eating and adiposity [108, 109, 171]. The combinations produced weight losses of up to $15 \%$ [144, 172]; most of the body weight loss was due to reduced eating because rats pair-fed to the amylin/leptin group lost similar amounts of weight [144]. Interestingly, body fat loss was more in the amylin/leptin-treated rats than in the pair-fed controls, which was also observed in the study by Seth and 
colleagues [171]. This was most likely due to the decrease in energy expenditure in pair-fed rats which was completely prevented in the amylin/leptin group [108, 109, 171]. During weight loss, the respiratory quotient was low in both the amylin/leptin and the pair-fed groups [108, $109,144,171,172]$, indicating preferential oxidation of fat. However, only the amylin/leptin group maintained a low respiratory quotient even in the weight stable phase. These metabolic effects in the amylin/leptin rats were paralleled by a reduced expression of genes for hepatic lipogenesis and increased expression of genes for lipid utilization [30, 108, 109, 146, 172]. Finally, the synergistic effects of leptin/amylin on fat pad size were much clearer than the effects on body weight. This is consistent with the concept that the control mechanisms involving amylin (and leptin) may primarily control adiposity not body weight (see also [171]). Overall, the amylin/leptin combination treatment prevented the suppression of energy metabolism that is typically seen in situations of negative energy balance which may, e.g., also be induced by simple dieting.

Progress has also been made to elucidate the potential mechanisms underlying the amylin/leptin synergy. This interaction seems to involve a direct effect of amylin on central leptin signaling. Most evidence points to the hypothalamus, specifically the VMH and potentially the ARC in that respect. The evidence is based on observations that amylin enhanced leptin signaling (as gauged by increased immunoreactivity of pSTAT3) specifically in the VMH $[108,109]$. This is particularly interesting in respect to the studies discussed in the previous sections (see "Role of histamine in amylin signaling") that had shown that amylin's eating-inhibitory effect is reduced by VMH administration of histamine $\mathrm{H} 1$ receptor antagonists and that both amylin's and leptin's effects on eating are blunted in $\mathrm{H} 1$ receptor-deficient mice $[96,105]$.

Increased pSTAT3 in the VMH may be causally linked to an amylin-induced upregulation of leptin receptor expression and hence direct enhancement of leptin action in VMH neurons. However, because pSTAT3 immunoreactivity was also enhanced in the AP [108], the exact site and mechanism of interaction between amylin and leptin require further studies; of note, the effect of even a large dose of acute leptin to increase pSTAT3 formation in the AP in amylin-pretreated rats was weak, and leptin did not enhance the amylin-induced c-Fos activation of AP neurons after single injection.

More evidence pointing to a hypothalamic site of interaction was the finding that leptin binding as determined by receptor autoradiography in the rat brain was increased in the ARC by the combination of amylin and leptin, and by amylin alone in the VMH and other hypothalamic sites, e.g., the DMH [109]. Finally, reduced leptin receptor expression was observed in the mediobasal hypothalamus in amylin-deficient mice [109]. It seems plausible that all the described effects of amylin on leptin signaling are causally linked and are part of a common mechanism, but this still needs to be studied; this should include the potential role of histamine and its necessity for the functional interaction of amylin and leptin.

One further point of consideration is how the pharmacological interactions of amylin and leptin on eating and adiposity relate to the physiological situation. As mentioned above, because rats that were pair-fed to amylintreated animals and received only leptin did not eat less or lose more weight than amylin-treated rats, leptin appeared to be unable to enhance the action of endogenous amylin [108]. Further, another question refers to the (physiological) relative importance of amylin and leptin in general. Obviously, the leptin-deficient mouse has a much stronger obese phenotype than the amylin-deficient mouse [17]. However, because obesity-associated leptin resistance prevents leptin from being effective when the effect apparently would be needed most, additional amylin may be a very effective alternative. Amylin may play an important modulatory role. In other words, the biological spectrum of leptin, which alone seems to produce strong signals on the "starvation side" (low leptin leads to a very strong drive to eat) but is relatively less active on the "obesity side" (high leptin is relative ineffective in preventing further eating) [173], may be extended; the combination of amylin plus leptin seems to produce a very effective eating inhibitory and adiposity signal, even in obese leptin-resistant animals.

\section{Therapeutic potential of amylin in anti-obesity therapy}

The amylin analogue pramlintide has been introduced as an adjunct to insulin into the therapy concepts of type 1 and type 2 diabetes; this was based on pramlintide's action to reduce postprandial glucagon secretion and to slow gastric emptying. Consistent with the described effects of amylin in rodents, the combination treatment of diabetics with insulin plus pramlintide was reported to lead to a significant body weight loss compared to insulin monotherapy [143]. Pramlintide has subsequently been shown to reduce energy intake in insulin-treated type 2 diabetics but also in obese non-diabetics [174, 175]. Pramlintide did not change the intake of specific macronutrients but rather appeared to decrease total eating. Further, pramlintide significantly increased the number of treated subjects that reached a body weight loss of more than $5 \%$ within a 16-week treatment period [176, 177]. Even though the decrease in total caloric intake was slightly attenuated after longer treatment periods, pramlintide's effect was maintained 
(e.g., total energy intake vs. control $-750 \mathrm{kcal}$ on day 3 of treatment vs. $-490 \mathrm{kcal}$ on day 43 of treatment [177, 178]). The effect of pramlintide depended on a general reduction in meal size but also on a reduction in unhealthy "fast food" intake and in the binge-eating tendency [177, $178]$.

Based on these studies with amylin monotherapy and the pre-clinical work using amylin and leptin combinations in rodents, Roth and colleagues [108, 148] tested the coadministration of the amylin and leptin analogues, pramlintide and metreleptin, respectively, in overweight and obese humans. The results were promising [108, 148] because they indicated that this combination therapy appeared to perform better than currently available nonsurgical approaches to treat obesity in humans. Body weight loss was about 5\% during a 4-week period when only pramlintide was given; continued treatment with either pramlintide or metreleptin for 20 weeks resulted in a total body weight loss of about $8 \%$. However, the combination treatment led to a weight loss of more than $12 \%$, and body weight was still on a decreasing projectory at the end of the 5-month study. Further, the number of patients reaching a certain percentage of body weight loss was significantly higher in the group receiving the combination treatment (e.g., 10\% decrease in body weight: metreleptin $21 \%$; pramlintide $35 \%$; pramlintide + metreleptin $56 \%$; $15 \%$ decrease: 11,5 and $28 \%$, respectively). More work is necessary to define the outcome of prolonged treatments including potential side effects, and in particular the consequences of cessation of treatment. Similar to other chronic diseases, maintained body weight loss may require continuous therapy, perhaps with slightly reduced doses (see also [179, 180]).

Is there a specific role for amylin treatment in females

Most animal studies using amylin have been performed only in male rats or mice. This is surprising, because not only has obesity become a huge public health problem almost worldwide but the incidence of morbid obesity in most European countries and in the USA seems to be much greater in women than in men. The increased obesity burden in women is also reflected by the fact that the majority of people undergoing bariatric surgery are women, e.g., over $80 \%$ in the USA and Switzerland, and the numbers seem to be similar in other countries. For this reason, the study on sex differences in the control of eating is important. In females, estradiol-or the lack of estradiol-appears to play the major role in specific effects of the female controls of eating. Estradiol is responsible for the cyclic decrease of eating on the day of estrus. Some of the best investigated phenomena indicate that one action of estradiol is to enhance the effect of endogenous satiation signals like CCK or GLP-1 [181-187].

Recently, Trevaskis and colleagues [188] (but see also [189]) reported that the action of (chronic) amylin on eating and body weight was stronger in ovariectomized rats that lack estradiol than in control rats or in ovariectomized rats receiving physiological estradiol replacement therapy; amylin's effect to reduce eating and body weight was about double. This was surprising, because most previous (acute) studies had reported an enhanced effect of satiating hormones by estradiol and not by the lack of it [181, 185, 187]. In Trevaskis' study, chronic amylin also partly restored the metabolic rate that was decreased as a consequence of ovariectomy [188]. Based on these results, it was concluded that amylin may be a promising anti-obesity therapy in postmenopausal women, i.e. in women with low endogenous estradiol levels.

Despite the clear effects reported by Trevaskis et al. [188], the interaction between amylin and estradiol seems complex. To our surprise, experiments with acute versus chronic amylin treatment yielded opposite effects. In other words, single acute injections of amylin were more effective in ovariectomized rats with physiological estradiol replacement than in rats without. Further, the amylin antagonist AC187 increased eating more in estradiolreplaced ovariectomized animals, pointing to the physiological relevance of this effect [189, 190]. These phenomena clearly require intensified studies; in fact, they may represent the first principal difference in the mechanisms of action of acute amylin versus chronic amylin (see also "Introduction-distinction between satiation and adiposity signals").

\section{Summary}

Amylin is a physiological control of meal size and, like other signals involved in satiation, the effect seems to rely mainly on a hindbrain action, involving the AP, the NTS, and the LPB. Chronic amylin treatment decreases while amylin antagonist treatment increases eating and body weight gain. This suggests that amylin may also act as an adiposity signal. The phenotype of amylin-responsive neurons and neurotransmitter signaling systems that are involved in amylin action have been partly elucidated; they seem to include noradrenergic and possibly dopaminergic and histaminergic systems. A clinically promising finding is that amylin seems to improve leptin sensitivity in obese animals. Subsequent human studies indicated that amylin/ leptin combination therapy may be an effective treatment for obesity, with efficiency beyond currently available pharmacotherapy. 
Acknowledgments The continued financial support of the Swiss National Science Foundation, the support of the Zurich Center of Integrative Human Physiology, the Novartis Foundation, the CibaGeigy Foundation, the Olga Mayenfisch Foundation, and the Vontobel Foundation are gratefully acknowledged. We thank Amylin Pharmaceuticals Inc. for some supply of amylin.

\section{References}

1. Young A, Denaro M (1998) Roles of amylin in diabetes and in regulation of nutrient load. Nutrition 14(6):524-527 (pii:S0899 900798000446)

2. Potes CS, Lutz TA (2010) Brainstem mechanisms of amylininduced anorexia. Physiol Behav 100(5):511-518. doi: 10.1016/j.physbeh.2010.03.001

3. Christopoulos G, Perry KJ, Morfis M, Tilakaratne N, Gao Y, Fraser NJ, Main MJ, Foord SM, Sexton PM (1999) Multiple amylin receptors arise from receptor activity-modifying protein interaction with the calcitonin receptor gene product. Mol Pharmacol 56(1):235-242

4. McLatchie LM, Fraser NJ, Main MJ, Wise A, Brown J, Thompson N, Solari R, Lee MG, Foord SM (1998) RAMPs regulate the transport and ligand specificity of the calcitoninreceptor-like receptor. Nature 393(6683):333-339. doi:10.1038/ 30666

5. Muff R, Buhlmann N, Fischer JA, Born W (1999) An amylin receptor is revealed following co-transfection of a calcitonin receptor with receptor activity modifying proteins-1 or -3 . Endocrinology 140(6):2924-2927

6. Hay DL, Christopoulos G, Christopoulos A, Poyner DR, Sexton PM (2005) Pharmacological discrimination of calcitonin receptor: receptor activity-modifying protein complexes. Mol Pharmacol 67(5):1655-1665. doi:10.1124/mol.104.008615

7. Morfis M, Tilakaratne N, Furness SG, Christopoulos G, Werry TD, Christopoulos A, Sexton PM (2008) Receptor activitymodifying proteins differentially modulate the $G$ protein-coupling efficiency of amylin receptors. Endocrinology 149(11): 5423-5431. doi:10.1210/en.2007-1735

8. Fischer JA, Muff R, Born W (2002) Functional relevance of G-protein-coupled-receptor-associated proteins, exemplified by receptor-activity-modifying proteins (RAMPs). Biochem Soc Trans 30(4):455-460. doi:10.1042/BST0300455

9. Becskei C, Riediger T, Zund D, Wookey P, Lutz TA (2004) Immunohistochemical mapping of calcitonin receptors in the adult rat brain. Brain Res 1030(2):221-233. doi:10.1016/ j.brainres.2004.10.012

10. Ueda T, Ugawa S, Saishin Y, Shimada S (2001) Expression of receptor-activity modifying protein (RAMP) mRNAs in the mouse brain. Brain Res Mol Brain Res 93(1):36-45 (pii: S016 9328X01001796)

11. Barth SW, Riediger T, Lutz TA, Rechkemmer G (2004) Peripheral amylin activates circumventricular organs expressing calcitonin receptor $\mathrm{a} / \mathrm{b}$ subtypes and receptor-activity modifying proteins in the rat. Brain Res 997(1):97-102

12. Sexton PM, Paxinos G, Kenney MA, Wookey PJ, Beaumont K (1994) In vitro autoradiographic localization of amylin binding sites in rat brain. Neuroscience 62(2):553-567. doi:10.1016/ 0306-4522(94)90388-3

13. Lutz TA (2010) The role of amylin in the control of energy homeostasis. Am J Physiol Regul Integr Comp Physiol 298(6):R1475-R1484. doi:10.1152/ajpregu.00703.2009

14. Geary N (2005) A new way of looking at eating. Am J Physiol Regul Integr Comp Physiol 288(6):R1444-R1446. doi:10.1152/ ajpregu.00066.2005
15. Lutz TA, Geary N (2008) Gastrointestinal factors in appetite and food research-animal research. In: Harris R, Mattes R (eds) Appetite and food intake: behavioral and physiological consideration. CRC Press, Boca Raton, pp 163-186

16. Butler PC, Chou J, Carter WB, Wang YN, Bu BH, Chang D, Chang JK, Rizza RA (1990) Effects of meal ingestion on plasma amylin concentration in NIDDM and nondiabetic humans. Diabetes 39(6):752-756

17. Lutz TA (2006) Amylinergic control of food intake. Physiol Behav 89(4):465-471. doi:10.1016/j.physbeh.2006.04.001

18. Arnelo U, Reidelberger R, Adrian TE, Larsson J, Permert J (1998) Sufficiency of postprandial plasma levels of islet amyloid polypeptide for suppression of feeding in rats. Am J Physiol 275(5 Pt 2):R1537-R1542

19. Mollet A, Meier S, Grabler V, Gilg S, Scharrer E, Lutz TA (2003) Endogenous amylin contributes to the anorectic effects of cholecystokinin and bombesin. Peptides 24(1):91-98

20. Roth JD, Coffey T, Jodka CM, Maier H, Athanacio JR, Mack CM, Weyer C, Parkes DG (2007) Combination therapy with amylin and peptide YY[3-36] in obese rodents: anorexigenic synergy and weight loss additivity. Endocrinology 148(12): 6054-6061. doi:10.1210/en.2007-0898

21. Trevaskis JL, Turek VF, Griffin PS, Wittmer C, Parkes DG, Roth JD (2010) Multi-hormonal weight loss combinations in diet-induced obese rats: therapeutic potential of cholecystokinin? Physiol Behav 100(2):187-195. doi:10.1016/j.physbeh. 2010.02.023

22. Gebre-Medhin S, Mulder H, Pekny M, Westermark G, Tornell J, Westermark P, Sundler F, Ahren B, Betsholtz C (1998) Increased insulin secretion and glucose tolerance in mice lacking islet amyloid polypeptide (amylin). Biochem Biophys Res Commun 250(2):271-277. doi:10.1006/bbrc.1998.9308

23. Devine E, Young AA (1998) Weight gain in male and female mice with amylin gene knockout. Diabetes 47:A317

24. Lutz TA (2005) Pancreatic amylin as a centrally acting satiating hormone. Curr Drug Targets 6(2):181-189

25. Reidelberger RD, Haver AC, Arnelo U, Smith DD, Schaffert CS, Permert J (2004) Amylin receptor blockade stimulates food intake in rats. Am J Physiol Regul Integr Comp Physiol 287(3): R568-R574. doi:10.1152/ajpregu.00213.2004

26. Rushing PA, Hagan MM, Seeley RJ, Lutz TA, D'Alessio DA, Air EL, Woods SC (2001) Inhibition of central amylin signaling increases food intake and body adiposity in rats. Endocrinology 142(11):5035

27. Mollet A, Gilg S, Riediger T, Lutz TA (2004) Infusion of the amylin antagonist AC 187 into the area postrema increases food intake in rats. Physiol Behav 81(1):149-155. doi:10.1016/ j.physbeh.2004.01.006

28. Lutz TA, Geary N, Szabady MM, Del Prete E, Scharrer E (1995) Amylin decreases meal size in rats. Physiol Behav 58(6):11971202

29. Morley JE, Suarez MD, Mattamal M, Flood JF (1997) Amylin and food intake in mice: effects on motivation to eat and mechanism of action. Pharmacol Biochem Behav 56(1):123-129. doi: 10.1016/S0091-3057(96)00168-2

30. Mack C, Wilson J, Athanacio J, Reynolds J, Laugero K, Guss S, Vu C, Roth J, Parkes D (2007) Pharmacological actions of the peptide hormone amylin in the long-term regulation of food intake, food preference, and body weight. Am J Physiol Regul Integr Comp Physiol 293(5):R1855-R1863. doi:10.1152/ ajpregu.00297.2007

31. Mack CM, Soares CJ, Wilson JK, Athanacio JR, Turek VF, Trevaskis JL, Roth JD, Smith PA, Gedulin B, Jodka CM, Roland BL, Adams SH, Lwin A, Herich J, Laugero KD, Vu C, Pittner R, Paterniti JR Jr, Hanley M, Ghosh S, Parkes DG (2010) Davalintide (AC2307), a novel amylin-mimetic peptide: enhanced 
pharmacological properties over native amylin to reduce food intake and body weight. Int J Obes (Lond) 34(2):385-395. doi: 10.1038/ijo.2009.238

32. Lutz TA, Senn M, Althaus J, Del Prete E, Ehrensperger F, Scharrer E (1998) Lesion of the area postrema/nucleus of the solitary tract (AP/NTS) attenuates the anorectic effects of amylin and calcitonin gene-related peptide (CGRP) in rats. Peptides 19(2):309-317

33. Fry M, Hoyda TD, Ferguson AV (2007) Making sense of it: roles of the sensory circumventricular organs in feeding and regulation of energy homeostasis. Exp Biol Med (Maywood) 232(1):14-26 (pii: 232/1/14)

34. Lutz TA, Althaus J, Rossi R, Scharrer E (1998) Anorectic effect of amylin is not transmitted by capsaicin-sensitive nerve fibers. Am J Physiol 274(6 Pt 2):R1777-R1782

35. Lutz TA, Del Prete E, Scharrer E (1994) Reduction of food intake in rats by intraperitoneal injection of low doses of amylin. Physiol Behav 55(5):891-895

36. Lutz TA, Del Prete E, Scharrer E (1995) Subdiaphragmatic vagotomy does not influence the anorectic effect of amylin. Peptides 16(3):457-462

37. Lutz TA, Mollet A, Rushing PA, Riediger T, Scharrer E (2001) The anorectic effect of a chronic peripheral infusion of amylin is abolished in area postrema/nucleus of the solitary tract (AP/ NTS) lesioned rats. Int J Obes Relat Metab Disord 25(7): 1005-1011. doi:10.1038/sj.ijo.0801664

38. Morley JE, Flood JF, Horowitz M, Morley PM, Walter MJ (1994) Modulation of food intake by peripherally administered amylin. Am J Physiol 267(1 Pt 2):R178-R184

39. Potes CS, Riediger T, Lutz TA (2010) Amylin induces ERK 1/2 phosphorylation in structures of the AP/NTS-LPB-Ce-BSTL axis. Appetite 54(3):670. doi:10.1016/j.appet.2010.04.164

40. Riediger T, Schmid HA, Lutz T, Simon E (2001) Amylin potently activates AP neurons possibly via formation of the excitatory second messenger cGMP. Am J Physiol Regul Integr Comp Physiol 281(6):R1833-R1843

41. Riediger T, Schmid HA, Lutz TA, Simon E (2002) Amylin and glucose co-activate area postrema neurons of the rat. Neurosci Lett 328(2):121-124

42. Riediger T, Zuend D, Becskei C, Lutz TA (2004) The anorectic hormone amylin contributes to feeding-related changes of neuronal activity in key structures of the gut-brain axis. Am $\mathrm{J}$ Physiol Regul Integr Comp Physiol 286(1):R114-R122. doi: 10.1152/ajpregu.00333.2003

43. Potes CS, Boyle CN, Riediger T, Lutz TA (in press) Involvement of the extracellular-signal regulated kinase 1/2 signaling pathway in amylin's eating inhibitory effect. Am J Physiol

44. Edwards GL, Gedulin BR, Jodka C, Dilts RP, Miller CC, Young A (1998) Area postrem (AP)-lesions block the regulation of gastric emptying by amylin. Neurogastroenterol Motil 10:26

45. Gedulin BR, Rink TJ, Young AA (1997) Dose-response for glucagonostatic effect of amylin in rats. Metabolism 46(1): 67-70 (pii: S0026-0495(97)90170-0)

46. Young AA, Gedulin B, Vine W, Percy A, Rink TJ (1995) Gastric emptying is accelerated in diabetic BB rats and is slowed by subcutaneous injections of amylin. Diabetologia 38(6):642-648

47. Wickbom J, Herrington MK, Permert J, Jansson A, Arnelo U (2008) Gastric emptying in response to IAPP and CCK in rats with subdiaphragmatic afferent vagotomy. Regul Pept 148(1-3): 21-25. doi:10.1016/j.regpep.2008.03.010

48. Potes CS, Lutz TA, Riediger T (2010) Identification of central projections from amylin-activated neurons to the lateral hypothalamus. Brain Res 1334:31-44. doi:10.1016/j.brainres.2010.03.114

49. Rowland NE, Crews EC, Gentry RM (1997) Comparison of Fos induced in rat brain by GLP-1 and amylin. Regul Pept 71(3):171-174 (pii: S0167-0115(97)01034-3)
50. Curran T, Morgan JI (1995) Fos: an immediate-early transcription factor in neurons. J Neurobiol 26(3):403-412. doi: $10.1002 /$ neu.480260312

51. Nishimoto S, Nishida E (2006) MAPK signalling: ERK5 versus ERK1/2. EMBO Rep 7:782-786

52. Torii S, Nakayama K, Yamamoto T, Nishida E (2004) Regulatory mechanisms and function of ERK MAP kinases. J Biochem 136:557-561

53. Yuan LL, Adams JP, Swank M, Sweatt JD, Johnston D (2002) Protein kinase modulation of dendritic $\mathrm{K}+$ channels in hippocampus involves a mitogen-activated protein kinase pathway. J Neurosci 22:4860-4868

54. Chang L, Karin M (2001) Mammalian MAP kinase signalling cascades. Nature 410:37-40

55. Dacquin R, Davey RA, Laplace C, Levasseur R, Morris HA, Goldring SR, Gebre-Medhin S, Galson DL, Zajac JD, Karsenty G (2004) Amylin inhibits bone resorption while the calcitonin receptor controls bone formation in vivo. J Cell Biol 164(4):509-514. doi:10.1083/jcb.200312135

56. Potes CS, Turek VF, Cole RL, Vu C, Roland BL, Roth JD, Riediger T, Lutz TA (2010) Noradrenergic neurons of the area postrema mediate amylin's hypophagic action. Am J Physiol Regul Integr Comp Physiol 299(2):R623-R631. doi:10.1152/ ajpregu.00791.2009

57. Babic T, Townsend RL, Patterson LM, Sutton GM, Zheng H, Berthoud HR (2009) Phenotype of neurons in the nucleus of the solitary tract that express CCK-induced activation of the ERK signaling pathway. Am J Physiol Regul Integr Comp Physiol 296(4):R845-R854. doi:10.1152/ajpregu.90531.2008

58. Sutton GM, Patterson LM, Berthoud HR (2004) Extracellular signal-regulated kinase $1 / 2$ signaling pathway in solitary nucleus mediates cholecystokinin-induced suppression of food intake in rats. J Neurosci 24(45):10240-10247. doi:10.1523/jneurosci. 2764-04.2004

59. Bhavsar S, Watkins J, Young A (1998) Synergy between amylin and cholecystokinin for inhibition of food intake in mice. Physiol Behav 64(4):557-561

60. Gedulin BR, Young AA (1998) Hypoglycemia overrides amylin-mediated regulation of gastric emptying in rats. Diabetes 47(1):93-97

61. Michel S, Becskei C, Erguven E, Lutz TA, Riediger T (2007) Diet-derived nutrients modulate the effects of amylin on c-Fos expression in the area postrema and on food intake. Neuroendocrinology 86(2):124-135. doi:10.1159/000107579

62. Riediger T, Michel S, Forster K, Lutz TA (2009) The ability of amylin to reduce eating depends on the protein content of the diet. Appetite 52(3):854. doi:10.1016/j.appet.2009.04.163

63. Smith GP (1996) The direct and indirect controls of meal size. Neurosci Biobehav Rev 20(1):41-46. doi:10.1016/0149-7634 (95)00038-G

64. Moran TH, Ladenheim EE, Schwartz GJ (2001) Within-meal gut feedback signaling. Int J Obes Relat Metab Disord 25(Suppl 5): S39-S41. doi:10.1038/sj.ijo.0801910

65. Schwartz GJ, McHugh PR, Moran TH (1991) Integration of vagal afferent responses to gastric loads and cholecystokinin in rats. Am J Physiol 261(1 Pt 2):R64-R69

66. Schwartz GJ, McHugh PR, Moran TH (1993) Gastric loads and cholecystokinin synergistically stimulate rat gastric vagal afferents. Am J Physiol 265(4 Pt 2):R872-R876

67. Young A (2005) Inhibition of gastric emptying. Adv Pharmacol 52:99-121. doi:10.1016/S1054-3589(05)52006-4

68. Reidelberger RD, Kelsey L, Heimann D (2002) Effects of amylin-related peptides on food intake, meal patterns, and gastric emptying in rats. Am J Physiol Regul Integr Comp Physiol 282(5):R1395-R1404. doi:10.1152/ajpregu.00597. 2001 
69. Gedulin BR, Jodka CM, Herrmann K, Young AA (2006) Role of endogenous amylin in glucagon secretion and gastric emptying in rats demonstrated with the selective antagonist, AC187. Regul Pept 137(3):121-127. doi:10.1016/j.regpep.2006.06.004

70. Aryangat AV, Gerich JE (2010) Type 2 diabetes: postprandial hyperglycemia and increased cardiovascular risk. Vasc Health Risk Manag 6:145-155

71. Kong MF, King P, Macdonald IA, Blackshaw PE, Horowitz M, Perkins AC, Armstrong E, Buchanan KD, Tattersall RB (1999) Euglycaemic hyperinsulinaemia does not affect gastric emptying in type I and type II diabetes mellitus. Diabetologia 42(3): 365-372. doi:10.1007/s001250051164

72. Kong MF, King P, Macdonald IA, Blackshaw PE, Perkins AC, Armstrong E, Buchanan KD, Tattersall RB (1998) Effect of euglycaemic hyperinsulinaemia on gastric emptying and gastrointestinal hormone responses in normal subjects. Diabetologia 41(4):474-481. doi:10.1007/s001250050932

73. Kong MF, King P, Macdonald IA, Stubbs TA, Perkins AC, Blackshaw PE, Moyses C, Tattersall RB (1997) Infusion of pramlintide, a human amylin analogue, delays gastric emptying in men with IDDM. Diabetologia 40(1):82-88. doi:10.1007/ s001250050646

74. Kong MF, Stubbs TA, King P, Macdonald IA, Lambourne JE, Blackshaw PE, Perkins AC, Tattersall RB (1998) The effect of single doses of pramlintide on gastric emptying of two meals in men with IDDM. Diabetologia 41(5):577-583. doi:10.1007/ s001250050949

75. Clementi G, Caruso A, Cutuli VM, de Bernardis E, Prato A, Amico-Roxas M (1996) Amylin given by central or peripheral routes decreases gastric emptying and intestinal transit in the rat. Experientia 52(7):677-679

76. Jodka CM, Green D, Young A, Gedulin B (1996) Amylin modulation of gastric emptying in rats depends upon an intact vagus. Diabetes 45:A235

77. Reidelberger RD, Arnelo U, Granqvist L, Permert J (2001) Comparative effects of amylin and cholecystokinin on food intake and gastric emptying in rats. Am J Physiol Regul Integr Comp Physiol 280(3):R605-R611

78. Young AA, Gedulin BR, Rink TJ (1996) Dose-responses for the slowing of gastric emptying in a rodent model by glucagon-like peptide (7-36) NH2, amylin, cholecystokinin, and other possible regulators of nutrient uptake. Metabolism 45(1):1-3

79. Asarian L, Eckel LA, Geary N (1998) Behaviorally specific inhibition of sham feeding by amylin. Peptides 19(10):1711-1718

80. Fitzsimons TJ, Le Magnen J (1969) Eating as a regulatory control of drinking in the rat. J Comp Physiol Psychol 67(3): 273-283

81. Arnelo U, Permert J, Adrian TE, Larsson J, Westermark P, Reidelberger RD (1996) Chronic infusion of islet amyloid polypeptide causes anorexia in rats. Am J Physiol 271(6 Pt 2): R1654-R1659

82. Becskei C, Grabler V, Edwards GL, Riediger T, Lutz TA (2007) Lesion of the lateral parabrachial nucleus attenuates the anorectic effect of peripheral amylin and CCK. Brain Res 1162:76-84. doi:10.1016/j.brainres.2007.06.016

83. Mollet A, Meier S, Riediger T, Lutz TA (2003) Histamine H1 receptors in the ventromedial hypothalamus mediate the anorectic action of the pancreatic hormone amylin. Peptides 24(1): $155-158$

84. Rinaman L, Hoffman GE, Dohanics J, Le WW, Stricker EM, Verbalis JG (1995) Cholecystokinin activates catecholaminergic neurons in the caudal medulla that innervate the paraventricular nucleus of the hypothalamus in rats. J Comp Neurol 360(2): 246-256

85. Chelikani PK, Haver AC, Reidelberger RD (2004) Comparison of the inhibitory effects of PYY(3-36) and PYY(1-36) on gastric emptying in rats. Am J Physiol Regul Integr Comp Physiol 287(5):R1064-R1070. doi:10.1152/ajpregu.00376.2004

86. Reidelberger RD, Haver AC, Apenteng BA, Anders KL, Steenson SM (2010) Effects of Exendin-4 alone and with peptide YY(3-36) on food intake and body weight in diet-induced obese rats. Obesity (Silver Spring). doi:10.1038/oby.2010.136

87. Riediger T, Bothe C, Becskei C, Lutz TA (2004) Peptide YY directly inhibits ghrelin-activated neurons of the arcuate nucleus and reverses fasting-induced c-Fos expression. Neuroendocrinology 79(6):317-326. doi:10.1159/000079842

88. Machidori H, Sakata T, Yoshimatsu H, Ookuma K, Fujimoto K, Kurokawa M, Yamatodani A, Wada H (1992) Zucker obese rats: defect in brain histamine control of feeding. Brain Res 590(1-2):180-186. doi:10.1016/0006-8993(92)91093-T

89. Sakata T, Yoshimatsu H, Kurokawa M (1997) Hypothalamic neuronal histamine: implications of its homeostatic control of energy metabolism. Nutrition 13(5):403-411

90. Sakata T, Fukagawa K, Ookuma K, Fujimoto K, Yoshimatsu H, Yamatodani A, Wada H (1988) Modulation of neuronal histamine in control of food intake. Physiol Behav 44(4-5):539-543. doi:10.1016/0031-9384(88)90316-2

91. Sakata T, Fukagawa K, Fujimoto K, Yoshimatsu H, Shiraishi T, Wada H (1988) Feeding induced by blockade of histamine H1receptor in rat brain. Experientia 44(3):216-218

92. Mercer LP, Kelley DS, Humphries LL, Dunn JD (1994) Manipulation of central nervous system histamine or histaminergic receptors (H1) affects food intake in rats. J Nutr 124(7):1029-1036

93. Mercer LD, Beart PM (1997) Histochemistry in rat brain and spinal cord with an antibody directed at the cholecystokininA receptor. Neurosci Lett 225(2):97-100 (pii: S0304-3940(97) 00197-3)

94. Schwartz JC, Arrang JM, Garbarg M, Pollard H, Ruat M (1991) Histaminergic transmission in the mammalian brain. Physiol Rev 71:1-51

95. Arrang J-M, Garbarg M, Lancelot J-C, Lecomte J-M, Pollard H, Robba M, Schunack W, Schwartz J-C (1987) Highly potent and selective ligands for histamine H3-receptors. Nature 327: 117-123

96. Mollet A, Lutz TA, Meier S, Riediger T, Rushing PA, Scharrer E (2001) Histamine H1 receptors mediate the anorectic action of the pancreatic hormone amylin. Am J Physiol Regul Integr Comp Physiol 281(5):R1442-R1448

97. Boyle CN, Stöcker D, Lutz TA (2011) Involvement of the histaminergic system in amylin and leptin action. Appetite 57(Suppl 1):S7

98. Cooper GJ (1994) Amylin compared with calcitonin gene-related peptide: structure, biology, and relevance to metabolic disease. Endocr Rev 15(2):163-201

99. Lutz TA, Tschudy S, Rushing PA, Scharrer E (2000) Amylin receptors mediate the anorectic action of salmon calcitonin (sCT). Peptides 21(2):233-238

100. Muff R, Born W, Fischer JA (1995) Calcitonin, calcitonin generelated peptide, adrenomedullin and amylin: homologous peptides, separate receptors and overlapping biological actions. Eur J Endocrinol 133(1):17-20

101. Riediger T, Schmid HA, Young AA, Simon E (1999) Pharmacological characterisation of amylin-related peptides activating subfornical organ neurones. Brain Res 837(1-2):161-168

102. Lutz TA, Del Prete E, Walzer B, Scharrer E (1996) The histaminergic, but not the serotoninergic, system mediates amylin's anorectic effect. Peptides 17(8):1317-1322

103. Morimoto T, Yamamoto Y, Mobarakeh JI, Yanai K, Watanabe T, Yamatodani A (1999) Involvement of the histaminergic system in leptin-induced suppression of food intake. Physiol Behav 67(5):679-683 (pii: S0031-9384(99)00123-7) 
104. Yoshimatsu H, Itateyama E, Kondou S, Tajima D, Himeno K, Hidaka S, Kurokawa M, Sakata T (1999) Hypothalamic neuronal histamine as a target of leptin in feeding behavior. Diabetes 48(12):2286-2291

105. Masaki T, Yoshimatsu H, Chiba S, Watanabe T, Sakata T (2001) Targeted disruption of histamine H1-receptor attenuates regulatory effects of leptin on feeding, adiposity, and UCP family in mice. Diabetes 50(2):385-391

106. Woods SC, D’Alessio DA (2008) Central control of body weight and appetite. J Clin Endocrinol Metab 93(11 Suppl 1):S37-S50. doi:10.1210/jc.2008-1630

107. Irani BG, Le Foll C, Dunn-Meynell AA, Levin BE (2009) Ventromedial nucleus neurons are less sensitive to leptin excitation in rats bred to develop diet-induced obesity. Am J Physiol Regul Integr Comp Physiol 296(3):R521-R527. doi:10.1152/ ajpregu.90842.2008

108. Roth JD, Roland BL, Cole RL, Trevaskis JL, Weyer C, Koda JE, Anderson CM, Parkes DG, Baron AD (2008) Leptin responsiveness restored by amylin agonism in diet-induced obesity: evidence from nonclinical and clinical studies. Proc Natl Acad Sci USA 105(20):7257-7262. doi:10.1073/pnas.0706473105

109. Turek VF, Trevaskis JL, Levin BE, Dunn-Meynell AA, Irani B, Gu G, Wittmer C, Griffin PS, Vu C, Parkes DG, Roth JD (2010) Mechanisms of amylin/leptin synergy in rodent models. Endocrinology 151(1):143-152. doi:10.1210/en.2009-0546

110. Lutz TA, Tschudy S, Mollet A, Geary N, Scharrer E (2001) Dopamine $\mathrm{D}(2)$ receptors mediate amylin's acute satiety effect. Am J Physiol Regul Integr Comp Physiol 280(6):R1697-R1703

111. Qian M, Johnson AE, Kallstrom L, Carrer H, Södersten P (1997) Cholecystokinin, dopamine D2 and $N$-methyl-D-aspartate binding sites in the nucleus of the solitary tract of the rat: possible relationship to ingestive behavior. Neuroscience 77:1077-1089

112. Barrachina MD, Martinez V, Wang L, Wei JY, Tache Y (1997) Synergistic interaction between leptin and cholecystokinin to reduce short-term food intake in lean mice. Proc Natl Acad Sci USA 94(19):10455-10460

113. Riedy CA, Chavez M, Figlewicz DP, Woods SC (1995) Central insulin enhances sensitivity to cholecystokinin. Physiol Behav 58:557-561

114. Woods SC (2005) Signals that influence food intake and body weight. Physiol Behav 86(5):709-716. doi:10.1016/j.physbeh. 2005.08.060

115. Surina-Baumgartner DM, Langhans W, Geary N (1995) Hepatic portal insulin antibody infusion increases, but insulin does not alter, spontaneous meal size in rats. Am J Physiol 269:R978R982

116. Crawley JN, Beinfeld MC (1983) Rapid development of tolerance to the behavioural actions of cholecystokinin. Nature 302(5910):703-706

117. West DB, Fey D, Woods SC (1984) Cholecystokinin persistently suppresses meal size but not food intake in free-feeding rats. Am J Physiol 246(5 Pt 2):R776-R787

118. Boyle CN, Rossier MM, Lutz TA (2011) Influence of high-fat feeding, diet-induced obesity, and hyperamylinemia on the sensitivity to acute amylin. Physiol Behav 104(1):20-28. doi: 10.1016/j.physbeh.2011.04.044

119. Woods SC (2004) Gastrointestinal satiety signals I. An overview of gastrointestinal signals that influence food intake. Am J Physiol Gastrointest Liver Physiol 286(1):G7-G13. doi:10.1152/ ajpgi.00448.2003

120. Pieber TR, Roitelman J, Lee Y, Luskey KL, Stein DT (1994) Direct plasma radioimmunoassay for rat amylin-(1-37): concentrations with acquired and genetic obesity. Am J Physiol 267(1 Pt 1):E156-E164

121. Leckstrom A, Lundquist I, Ma Z, Westermark P (1999) Islet amyloid polypeptide and insulin relationship in a longitudinal study of the genetically obese (ob/ob) mouse. Pancreas 18(3): 266-273

122. Boyle CN, Rossier MM, Lutz TA (2010) Diet-induced obesity hyperamylinemia and amylin sensitivity. Appetite 54(3):636

123. Enoki S, Mitsukawa T, Takemura J, Nakazato M, Aburaya J, Toshimori H, Matsukara S (1992) Plasma islet amyloid polypeptide levels in obesity, impaired glucose tolerance and noninsulin-dependent diabetes mellitus. Diabetes Res Clin Pract 15(1):97-102

124. Hanabusa T, Kubo K, Oki C, Nakano Y, Okai K, Sanke T, Nanjo K (1992) Islet amyloid polypeptide (IAPP) secretion from islet cells and its plasma concentration in patients with noninsulin-dependent diabetes mellitus. Diabetes Res Clin Pract 15(1):89-96

125. Gloy VL, Lutz TA, Langhans W, Geary N, Hillebrand JJ (2010) Basal plasma levels of insulin, leptin, ghrelin, and amylin do not signal adiposity in rats recovering from forced overweight. Endocrinology 151(9):4280-4288. doi:10.1210/en.2010-0439

126. Boyle CN, Lutz TA (2011) Amylinergic control of food intake in lean and obese rodents. Physiol Behav. doi:10.1016/ j.physbeh.2011.02.015

127. Roth JD, Hughes H, Kendall E, Baron AD, Anderson CM (2006) Antiobesity effects of the beta-cell hormone amylin in dietinduced obese rats: effects on food intake, body weight, composition, energy expenditure, and gene expression. Endocrinology 147(12):5855-5864. doi:10.1210/en.2006-0393

128. Rushing PA, Hagan MM, Seeley RJ, Lutz TA, Woods SC (2000) Amylin: a novel action in the brain to reduce body weight. Endocrinology 141(2):850-853

129. Wielinga PY, Alder B, Lutz TA (2007) The acute effect of amylin and salmon calcitonin on energy expenditure. Physiol Behav 91(2-3):212-217. doi:10.1016/j.physbeh.2007.02.012

130. Wielinga PY, Lowenstein C, Muff S, Munz M, Woods SC, Lutz TA (2010) Central amylin acts as an adiposity signal to control body weight and energy expenditure. Physiol Behav 101(1): 45-52. doi:10.1016/j.physbeh.2010.04.012

131. Chavez M, Kaiyala K, Madden LJ, Schwartz MW, Woods SC (1995) Intraventricular insulin and the level of maintained body weight in rats. Behav Neurosci 109:528-531

132. Munzberg H (2010) Leptin-signaling pathways and leptin resistance. Forum Nutr 63:123-132. doi:10.1159/000264400

133. Banks WA (2010) Blood-brain barrier as a regulatory interface. Forum Nutr 63:102-110. doi:10.1159/000264398

134. Banks WA (2008) The blood-brain barrier: connecting the gut and the brain. Regul Pept 149(1-3):11-14. doi:10.1016/j.regpep. 2007.08.027

135. Banks WA (2001) Leptin transport across the blood-brain barrier: implications for the cause and treatment of obesity. Curr Pharm Des 7(2):125-133

136. Banks WA, Coon AB, Robinson SM, Moinuddin A, Shultz JM, Nakaoke R, Morley JE (2004) Triglycerides induce leptin resistance at the blood-brain barrier. Diabetes 53(5):1253-1260

137. Banks WA, DiPalma CR, Farrell CL (1999) Impaired transport of leptin across the blood-brain barrier in obesity. Peptides 20(11):1341-1345 (pii: S0196-9781(99)00139-4)

138. Benoit SC, Kemp CJ, Elias CF, Abplanalp W, Herman JP, Migrenne S, Lefevre AL, Cruciani-Guglielmacci C, Magnan C, Yu F, Niswender K, Irani BG, Holland WL, Clegg DJ (2009) Palmitic acid mediates hypothalamic insulin resistance by altering PKC-theta subcellular localization in rodents. J Clin Invest 119(9):2577-2589. doi:10.1172/jci36714

139. Clegg DJ, Benoit SC, Reed JA, Woods SC, Dunn-Meynell A, Levin BE (2005) Reduced anorexic effects of insulin in obesityprone rats fed a moderate-fat diet. Am J Physiol Regul Integr Comp Physiol 288(4):R981-R986. doi:10.1152/ajpregu.00675. 2004 
140. Clegg DJ, Gotoh K, Kemp C, Wortman MD, Benoit SC, Brown LM, D'Alessio D, Tso P, Seeley RJ, Woods SC (2011) Consumption of a high-fat diet induces central insulin resistance independent of adiposity. Physiol Behav 103(1):10-16. doi: 10.1016/j.physbeh.2011.01.010

141. Knight ZA, Hannan KS, Greenberg ML, Friedman JM (2010) Hyperleptinemia is required for the development of leptin resistance. PLoS ONE 5(6):e11376. doi:10.1371/journal.pone. 0011376

142. Buse JB, Weyer C, Maggs DG (2002) Amylin replacement with pramlintide in type 1 and type 2 diabetes: a physiological approach to overcome barriers with insulin therapy. Clin Diabetes 20(3):137-144

143. Hollander P, Maggs DG, Ruggles JA, Fineman M, Shen L, Kolterman OG, Weyer C (2004) Effect of pramlintide on weight in overweight and obese insulin-treated type 2 diabetes patients. Obes Res 12(4):661-668. doi:10.1038/oby.2004.76

144. Trevaskis J, Coffey T, Cole R, Lei C, Wittmer C, Walsh B, Weyer C, Koda J, Baron A, Parkes D, Roth J (2008) Amylinmediated restoration of leptin responsiveness in diet-induced obesity: magnitude and mechanisms. Endocrinology 149(11): 5679-5687

145. Weyer C, Maggs DG, Young AA, Kolterman OG (2001) Amylin replacement with pramlintide as an adjunct to insulin therapy in type 1 and type 2 diabetes mellitus: a physiological approach toward improved metabolic control. Curr Pharm Des 7(14):1353-1373

146. Ashwell M, Meade CJ (1978) Obesity: do fat cells from genetically obese mice (C57BL/6 J ob/ob) have an innate capacity for increased fat storage? Diabetologia 15(6):465-470

147. Roth JD, Trevaskis JL, Turek VF, Parkes DG (2010) "Weighing in" on synergy: preclinical research on neurohormonal anti-obesity combinations. Brain Res 1350:86-94. doi:10.1016/ j.brainres.2010.01.027

148. Ravussin E, Smith SR, Mitchell JA, Shringarpure R, Shan K, Maier H, Koda JE, Weyer C (2009) Enhanced weight loss with pramlintide/metreleptin: an integrated neurohormonal approach to obesity pharmacotherapy. Obesity (Silver Spring) 17(9): 1736-1743. doi:10.1038/oby.2009.184

149. Covasa M, Marcuson JK, Ritter RC (2001) Diminished satiation in rats exposed to elevated levels of endogenous or exogenous cholecystokinin. Am J Physiol Regul Integr Comp Physiol 280(2):R331-R337

150. Covasa M, Ritter RC (1998) Rats maintained on high-fat diets exhibit reduced satiety in response to $\mathrm{CCK}$ and bombesin. Peptides 19(8):1407-1415 (pii: S0196-9781(98)00096-5)

151. Covasa M, Ritter RC (1999) Reduced sensitivity to the satiation effect of intestinal oleate in rats adapted to high-fat diet. Am J Physiol 277(1 Pt 2):R279-R285

152. Swartz TD, Duca FA, Covasa M (2010) Differential feeding behavior and neuronal responses to CCK in obesity-prone and -resistant rats. Brain Res 1308:79-86. doi:10.1016/j.brainres. 2009.10.045

153. Banks WA, Kastin AJ, Maness LM, Huang W, Jaspan JB (1995) Permeability of the blood-brain barrier to amylin. Life Sci 57(22):1993-2001 (pii: 002432059502197Q)

154. Banks WA, Kastin AJ (1998) Differential permeability of the blood-brain barrier to two pancreatic peptides: insulin and amylin. Peptides 19(5):883-889 (pii: S0196-9781(98)00018-7)

155. Reinehr T, de Sousa G, Niklowitz P, Roth CL (2007) Amylin and its relation to insulin and lipids in obese children before and after weight loss. Obesity (Silver Spring) 15(8):2006-2011. doi: 10.1038/oby.2007.239

156. Levin BE, Dunn-Meynell AA (2002) Reduced central leptin sensitivity in rats with diet-induced obesity. Am J Physiol Regul
Integr Comp Physiol 283(4):R941-R948. doi:10.1152/ajpregu. 00245.2002

157. Levin BE, Dunn-Meynell AA (2002) Defense of body weight depends on dietary composition and palatability in rats with diet-induced obesity. Am J Physiol Regul Integr Comp Physiol 282(1):R46-R54

158. Boyle CN, Munz M, Wielinga PY, Stöcker D, Lutz TA (2010) Short-term, but not extended, access to palatable diet diminishes amylin responsiveness in rat. Appetite 54(3):636

159. Baldo BA, Kelley AE (2001) Amylin infusion into rat nucleus accumbens potently depresses motor activity and ingestive behavior. Am J Physiol Regul Integr Comp Physiol 281(4): R1232-R1242

160. Levin BE, Dunn-Meynell AA (2000) Defense of body weight against chronic caloric restriction in obesity-prone and -resistant rats. Am J Physiol Regul Integr Comp Physiol 278(1):R231R237

161. Levin BE, Dunn-Meynell AA, Balkan B, Keesey RE (1997) Selective breeding for diet-induced obesity and resistance in Sprague-Dawley rats. Am J Physiol 273(2 Pt 2):R725-R730

162. Ogawa A, Harris V, McCorkle SK, Unger RH, Luskey KL (1990) Amylin secretion from the rat pancreas and its selective loss after streptozotocin treatment. J Clin Invest 85(3):973-976. doi:10.1172/JCI114528

163. Pieber TR, Stein DT, Ogawa A, Alam T, Ohneda M, McCorkle K, Chen L, McGarry JD, Unger RH (1993) Amylin-insulin relationships in insulin resistance with and without diabetic hyperglycemia. Am J Physiol 265(3 Pt 1):E446-E453

164. Blackard WG, Clore JN, Kellum JM (1994) Amylin/insulin secretory ratios in morbidly obese man: inverse relationship with glucose disappearance rate. J Clin Endocrinol Metab 78(5):1257-1260

165. Qi D, Cai K, Wang O, Li Z, Chen J, Deng B, Qian L, Le Y (2009) Fatty acids induce amylin expression and secretion by pancreatic \{beta\}-cells. Am J Physiol Endocrinol Metab. doi: 10.1152/ajpendo.00242.2009

166. Isaksson B, Wang F, Permert J, Olsson M, Fruin B, Herrington MK, Enochsson L, Erlanson-Albertsson C, Arnelo U (2005) Chronically administered islet amyloid polypeptide in rats serves as an adiposity inhibitor and regulates energy homeostasis. Pancreatology 5(1):29-36. doi:10.1159/000084488

167. Osaka T, Tsukamoto A, Koyama Y, Inoue S (2008) Central and peripheral administration of amylin induces energy expenditure in anesthetized rats. Peptides 29(6):1028-1035. doi:10.1016/ j.peptides.2008.02.002

168. Wielinga PY, Löwenstein C, Alder B, Lutz TA (2008) Effect of peripheral and central amylin on energy expenditure and body temperature. Appetite 91:409

169. Osto M, Wielinga PY, Alder B, Walser N, Lutz TA (2007) Modulation of the satiating effect of amylin by central ghrelin, leptin and insulin. Physiol Behav 91(5):566-572. doi:10.1016/ j.physbeh.2007.03.017

170. Rushing PA, Lutz TA, Seeley RJ, Woods SC (2000) Amylin and insulin interact to reduce food intake in rats. Horm Metab Res 32(2):62-65. doi: $10.1055 / \mathrm{s}-2007-978590$

171. Seth R, Knight WD, Overton JM (2010) Combined amylinleptin treatment lowers blood pressure and adiposity in lean and obese rats. Int J Obes (Lond). doi:10.1038/ijo.2010.262

172. Trevaskis JL, Lei C, Koda JE, Weyer C, Parkes DG, Roth JD (2009) Interaction of leptin and amylin in the long-term maintenance of weight loss in diet-induced obese rats. Obesity (Silver Spring). doi:10.1038/oby.2009.187

173. Schwartz MW, Woods SC, Seeley RJ, Barsh GS, Baskin DG, Leibel RL (2003) Is the energy homeostasis system inherently biased toward weight gain? Diabetes 52(2):232-238 
174. Chapman I, Parker B, Doran S, Feinle-Bisset C, Wishart J, Lush $\mathrm{CW}$, Chen K, Lacerte C, Burns C, McKay R, Weyer C, Horowitz M (2007) Low-dose pramlintide reduced food intake and meal duration in healthy, normal-weight subjects. Obesity (Silver Spring) 15(5):1179-1186. doi:10.1038/oby.2007.626

175. Chapman I, Parker B, Doran S, Feinle-Bisset C, Wishart J, Strobel S, Wang Y, Burns C, Lush C, Weyer C, Horowitz M (2005) Effect of pramlintide on satiety and food intake in obese subjects and subjects with type 2 diabetes. Diabetologia 48(5):838-848. doi:10.1007/s00125-005-1732-4

176. Aronne L, Fujioka K, Aroda V, Chen K, Halseth A, Kesty NC, Burns C, Lush CW, Weyer C (2007) Progressive reduction in body weight after treatment with the amylin analog pramlintide in obese subjects: a phase 2, randomized, placebo-controlled, dose-escalation study. J Clin Endocrinol Metab 92(8):29772983. doi:10.1210/jc.2006-2003

177. Smith SR, Aronne LJ, Burns CM, Kesty NC, Halseth AE, Weyer C (2008) Sustained weight loss following 12-month pramlintide treatment as an adjunct to lifestyle intervention in obesity. Diabetes Care 31(9):1816-1823. doi:10.2337/dc08-0029

178. Smith SR, Blundell JE, Burns C, Ellero C, Schroeder BE, Kesty NC, Chen KS, Halseth AE, Lush CW, Weyer C (2007) Pramlintide treatment reduces 24-h caloric intake and meal sizes and improves control of eating in obese subjects: a 6-wk translational research study. Am J Physiol Endocrinol Metab 293(2): E620-E627. doi:10.1152/ajpendo.00217.2007

179. Trevaskis JL, Parkes DG, Roth JD (2010) Insights into amylinleptin synergy. Trends Endocrinol Metab 21(8):473-479. doi: 10.1016/j.tem.2010.03.006

180. Trevaskis JL, Lei C, Koda JE, Weyer C, Parkes DG, Roth JD (2010) Interaction of leptin and amylin in the long-term maintenance of weight loss in diet-induced obese rats. Obesity (Silver Spring) 18(1):21-26. doi:10.1038/oby.2009.187

181. Asarian L, Geary N (2007) Estradiol enhances cholecystokinindependent lipid-induced satiation and activates estrogen receptor-alpha-expressing cells in the nucleus tractus solitarius of ovariectomized rats. Endocrinology 148(12):5656-5666. doi: 10.1210/en.2007-0341
182. Asarian L, Geary N (2002) Cyclic estradiol treatment normalizes body weight and restores physiological patterns of spontaneous feeding and sexual receptivity in ovariectomized rats. Horm Behav 42(4):461-471 (pii: S0018506X02918350)

183. Thammacharoen S, Geary N, Lutz TA, Ogawa S, Asarian L (2009) Divergent effects of estradiol and the estrogen receptoralpha agonist PPT on eating and activation of PVN CRH neurons in ovariectomized rats and mice. Brain Res 1268:88-96. doi:10.1016/j.brainres.2009.02.067

184. Thammacharoen S, Lutz TA, Geary N, Asarian L (2008) Hindbrain administration of estradiol inhibits feeding and activates estrogen receptor-alpha-expressing cells in the nucleus tractus solitarius of ovariectomized rats. Endocrinology 149(4):1609-1617. doi:10.1210/en.2007-0340

185. Meyer MR, Clegg DJ, Prossnitz ER, Barton M (2011) Obesity, insulin resistance and diabetes: sex differences and role of oestrogen receptors. Acta Physiol (Oxf). doi:10.1111/j.17481716.2010.02237.x

186. Park CJ, Zhao Z, Glidewell-Kenney C, Lazic M, Chambon P, Krust A, Weiss J, Clegg DJ, Dunaif A, Jameson JL, Levine JE (2011) Genetic rescue of nonclassical ERalpha signaling normalizes energy balance in obese Eralpha-null mutant mice. J Clin Invest 121(2):604-612. doi:10.1172/jci41702

187. Eckel LA, Geary N (1999) Endogenous cholecystokinin's satiating action increases during estrus in female rats. Peptides 20(4):451-456

188. Trevaskis JL, Turek VF, Wittmer C, Griffin PS, Wilson JK, Reynolds JM, Zhao Y, Mack CM, Parkes DG, Roth JD (2010) Enhanced amylin-mediated body weight loss in estradiol-deficient diet-induced obese rats. Endocrinology 151(12):56575668. doi:10.1210/en.2010-0590

189. Lutz TA (2011) Amylin may offer (more) help to treat postmenopausal obesity. Endocrinology 152(1):1-3. doi:10.1210/en. 2010-1158

190. Asarian L, Boyle CN, Lutz TA (2011) Estradiol (E2) increases the acute eating-inhibitory effect of amylin in ovariectomized (OVX) rats. Appetite 57(Suppl 1):S2 